\title{
Informational Regulation and Informational Standing: Akins and Beyond
}

\section{Citation}

Cass R. Sunstein Informational Regulation and Informational Standing: Akins and Beyond, $147 \mathrm{U}$. Pa. L. Rev. 613 (1999).

\section{Published Version}

http://scholarship.law.upenn.edu/penn_law_review/vol147/iss3/2/

\section{Permanent link}

http://nrs.harvard.edu/urn-3:HUL.InstRepos:12911336

\section{Terms of Use}

This article was downloaded from Harvard University's DASH repository, and is made available under the terms and conditions applicable to Other Posted Material, as set forth at http:// nrs.harvard.edu/urn-3:HUL.InstRepos:dash.current.terms-of-use\#LAA

\section{Share Your Story}

The Harvard community has made this article openly available.

Please share how this access benefits you. Submit a story.

Accessibility 


\title{
INFORMATIONAL REGULATION AND INFORMATIONAL STANDING: $A K I N S$ AND BEYOND
}

\author{
CASS R. SUNSTEIN ${ }^{\dagger}$
}

As Government programs and policies become more complex and far reaching, we must be sensitive to the articulation of new rights of action that do not have clear analogs in our common-law tradition.... In my view, Congress has the power to define injuries and articulate chains of causation that will give rise to a case or controversy where none existed before ....

If today's decision is correct, it is within the power of Congress to authorize any interested person to manage (through the courts) the Executive's enforcement of any law that includes a requirement for the filing and public availability of a piece of paper. ${ }^{2}$

\section{INTRODUCTION}

It is often said that the American economy has been shifting from one based on industrial development to one based on the creation and dissemination of information. ${ }^{3}$ Whether or not this is so, there can be little doubt that a number of statutes in the last forty years were designed to ensure disclosure of information, and that mandatory disclosure is an increasingly pervasive and important regulatory tool. Indeed, informational regulation, or regulation through disclosure, has become one of the most striking developments in the last generation of American law. ${ }^{4}$

† Karl N. Llewellyn Distinguished Service Professor, University of Chicago Law School and Department of Political Science. I am grateful to Jack Goldsmith and Richard Posner for valuable comments on a previous draft.

${ }^{1}$ Lujan v. Defenders of Wildlife, 504 U.S. 555, 580 (1992) (Kennedy, J., concurring in part and concurring in the judgment).

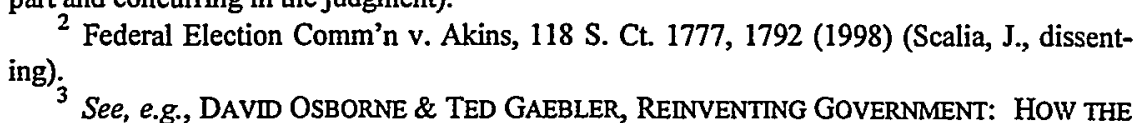
ENTREPRENEURIAL SPIRIT IS TRANSFORMING THE PUBLIC SECTOR 15-16 (1992) (describing the failure of government bureaucracy to adjust to the new "knowledge-based economy").

4 See STEPHEN BREYER, REGULATION AND ITS REFORM 171-75 (1982) (discussing alternatives to classical regulation that overcome some of the information problems associated with regulation); WESLEY A. MAGAT \& W. KIP VISCUSI, INFORMATIONAL APPROACHES TO REGULATION (1992) (discussing, in depth, various informational approaches to regulation); ANTHONY OGUS, REGULATION: LEGAL FORM AND ECONOMIC THEORY 121-49 (1994) (identifying "mandatory disclosure" and "control of false or misleading information" as the two broad categories of information regulation, and discussing the justifications for each); 
Informational regulation takes several different forms. Sometimes the government attempts to improve the behavior of private industry by requiring companies to disclose information about, for example, toxic releases, the contents of food and drink, and workplace injuries. Prominent examples include the Emergency Planning and Community Right-to-Know Act ${ }^{5}$ and regulations governing the disclosure of the nutritional content of food. ${ }^{6}$ Here the goal is to fortify either market mechanisms or political checks on private behavior. ${ }^{7}$ Sometimes the government attempts to control its own agents through compulsory production and disclosure of information; consider the National Environmental Policy Act of 1969 ("NEPA"), the Freedom of Information Act ("FOIA"), and the Federal Election Campaign Act ("FECA"). ${ }^{10}$ Here the goal is to allow more in the way of public monitoring of governmental decisions, with particular issues (insufficient environmental concern, unlawful behavior during campaigns, official corruption) receiving special attention.

Legal struggles between those seeking information on the one hand, and government or others required by law to disclose information on the other,

Paul R. Kleindorfer \& Eric W. Orts, Informational Regulation of Environmental Risks, 18 RISK ANALYSIS 155 (1998) (examining the informational regulation of environmental risks from an economic perspective); Eric W. Orts, Reflexive Environmental Law, 89 Nw. U. L. REV. 1227, 1258-64, 1313-40 (1995) (advancing "reflexive law" as a means of regulating complex societies by adopting procedures rather than "detailed pronouncements of acceptable behavior," and advocating mandatory environmental audits as a type of reflexive environmental law).

${ }^{5} 42$ U.S.C. $\$ \S 11,001-50$ (1994) (establishing notification and reporting requirements relating to hazardous chemicals).

${ }^{6}$ See Nutrition Labeling and Education Act of 1990, Pub. L. No. 101-535, 104 Stat. 2353 (codified as amended at 21 U.S.C. $\$ 343$ (1994)). The most important provisions of this Act are codified at 21 U.S.C. $\S 343(r)$.

7 Throughout this Article, a reference to the "goals" or "purposes" of a statute requiring disclosure is designed not to capture the actual political forces that give rise to the law, but instead to put the law in a sympathetic light and to make the best sense of it. Undoubtedly, statutes that require disclosure-like all statutes-owe a great deal to interest group pressures, some of them pernicious. The existence of informational regulation rather than more aggressive controls may reflect the power of self-interested private groups attempting to minimize government's presence in their lives. So, too, the existence of informational regulation may reflect the efforts of self-interested, entrepreneurial groups. Both of these possibilities are connected to the risk that informational regulation will be futile or excessively expensive.

842 U.S.C. $\$ \$ 4321-4370$ d (1994) (establishing the Council on Environmental Quality and related federal environmental departments to carry out research and reporting responsibilities).

95 U.S.C. $\$ 552$ (1994 \& Supp. III 1997) (requiring agencies to publish public information in the Federal Register and to make nonpublished materials available to persons who request them).

${ }^{10} 2$ U.S.C. $\$ \$ 431-56$ (1994 \& Supp. III 1997) (requiring candidates for federal office to disclose certain types of campaign contributions). 
promise to provide many of the most important public law cases in the next several decades. The outcome of these struggles will have significant consequences. Victories for those who seek to withhold information are important not only because they dispose of the case at hand, but also because they give similarly situated people, in both government and the private sector, a clear signal about whether they must disclose information outside of the context of litigated cases. This signal will inevitably affect behavior well before cases arise.

For many years it has been unclear whether, and under what circumstances, a citizen will have standing in federal court to seek access to information held by the government. FOIA gives standing to all persons to obtain a wide range of information; ${ }^{11}$ there is no requirement that the information involve a particular citizen, or even be shown to be relevant to her professional or personal concerns. Mere curiosity appears to be enough. Anyone is entitled to obtain any information that FOIA makes public. ${ }^{12}$ Is FOIA therefore unconstitutional? NEPA requires the government to compile and disclose environmentally relevant information before it proceeds with projects having a major impact on the environment. ${ }^{13}$ But who, exactly, may sue to require preparation of an environmental impact statement ("EIS")? Is curiosity enough here as well? FECA imposes a wide range of reporting and disclosure requirements on all "political committees." 14 Does this mean that any American can bring suit against the Federal Election Commission ("FEC") to require it to enforce the law?

11 See 5 U.S.C. $\$ 552$ (requiring agencies to make certain information available to the public).

${ }^{12}$ In Akins v. Federal Election Comm'n, 101 F.3d 731 (D.C. Cir. 1996) (en banc), vacated, 118 S. Ct. 1777 (1998), the court gave the closest thing to an explanation of the prevailing view:

Congress can create a legal right (and, typically, a cause of action to protect that right) the interference with which will create an Article III injury. Such a legal right can be given to all persons in the country. In that event, any person whose individual right has been frustrated or interfered with has standing to sue, even though all other persons have the same right, without the claim being regarded as a generalized grievance. That is why anyone denied information under the Freedom of Information Act (FOIA) has standing to sue regardless of his or her reasons for suing. Id. at 736 (citations omitted).

1342 U.S.C. $\$ \S 4321-4370$ d. Specifically, 42 U.S.C. $\$ 4332$ provides that "all agencies of the Federal Government shall ... include in every recommendation or report on proposals for legislation and other major Federal actions significantly affecting the quality of the human environment, a detailed statement ... on (i) the environmental impact of the proposed action."

14 2 U.S.C. $\$ \S 431-56$ (1994 \& Supp. III 1997). 
The Supreme Court has now started to sort out this area of the law. Federal Election Commission v. Akins ${ }^{15}$ is by far the most important pronouncement on the general issue of standing to obtain information. More than that, it reorients the general law of standing in several significant ways. In particular, the Court appears to have held that any citizen has standing to sue under FECA; that Congress is permitted to grant standing to all or many citizens, even if they are seeking to redress a "generalized grievance"; that the key question, in cases involving information or anything else, is what the relevant source of law actually says; and that Article II is no barrier to suits brought by citizens whose interests are not substantially different from those of the citizenry as a whole. ${ }^{16}$ The most important step here is the suggestion that Congress can overcome the barrier to "generalized grievances," for this barrier is likely to be crucial to plaintiffs seeking information.

At the same time, the Court's opinion marks a significant new development in the law of "redressability," a development that is in considerable tension with previous cases. And the Court's opinion raises or leaves open a host of new questions about the circumstances in which citizens may bring suits to obtain information. It is no wonder that Justice Scalia wrote a passionate dissent, suggesting that the Court's opinion violates not only Article III but Article II as well. ${ }^{17}$

Remarkably, the emerging law governing standing to obtain information has yet to receive academic attention. The basic purpose of this Article is to begin to fill this gap, above all by exploring the intersection between the law of standing and the wide range of statutes mandating public disclosure. In the process it will be necessary to offer an understanding of the extent to which disclosure of information has become a central part of the American regulatory state - as central, in its way, as command-and-control regulation and economic incentives. As we shall see, it is impossible to understand the standing questions without understanding the regulatory questions as well. As we shall also see, an understanding of the emerging law of standing to receive information has a set of implications for the law of standing in general.

The Supreme Court's decision in Akins is the vehicle for much of the analysis, because the Akins Court covers a strikingly wide range of standing issues, in a way that is full of implications for the future. My most general claim is that at least in information cases, the question of standing is for

15118 S. Ct. 1777 (1998).

16 See infra Part II (discussing the Court's holding and analysis in Akins).

17 See Akins, 118 S. Ct. at 1789-92 (Scalia, J., dissenting). 
congressional rather than judicial resolution. It follows that whether someone has informational standing depends on what Congress has said. If Congress creates a legal right to information and gives people the authority to vindicate that right in court, the standing question is essentially resolved. Insofar as it recognizes this point, Akins appears to vindicate the passage from Justice Kennedy's important concurring opinion in Lujan v. Defenders of Wildlife, quoted above, ${ }^{18}$ and in the process suggests that Justice Scalia's prophecy, also quoted above, ${ }^{19}$ will eventually be proved correct.

This Article comes in four parts. Part I discusses the use of information as a regulatory tool, partly as a background for the question of standing, and partly as a brief, freestanding treatment of an important development in regulatory law. The basic point here is that informational strategies are displacing (and have significant advantages over) command-and-control approaches. In some contexts, however, they risk futility and excessive cost, partly because of the difficulty that people face in dealing with lowprobability events.

Part II deals with Akins itself and outlines the several clarifications of, and departures from, current law. The argument here is that the Court has revised the "injury in fact" test so as to focus attention on what kind of harm Congress sought to prevent; in the process the Court has made clear, for the first time, that Congress can grant standing to someone who suffers a quite generalized injury. Part III evaluates the Akins Court's approach to informational standing, with particular emphasis on the relationships among standing, injury in fact, congressional instructions, and Article III. I argue that the Court's decision suggests the right approach for informational standing, but that the decision leaves open a number of questions, both practical and conceptual.

Part IV discusses the future, with reference to a number of actual and hypothetical cases. I attempt to show how an understanding of informational regulation sheds light on the question of informational standing. The most important claim is that if Congress creates an interest in receiving information, and gives people a right to vindicate that interest in court, then it has acted consistently with Article III. This claim bears in turn on the general law of standing and the whole notion of "injury in fact," especially, but not only, in the context of information. It suggests that whether there is an

18504 U.S. 555, 580 (1992) (Kennedy, J., concurring in part and concurring in the judgment); see supra text accompanying note 1 .

${ }^{19}$ See supra text accompanying note 2 . 
"injury" cannot be decided in the abstract, or solely by reference to the "facts"; it turns instead on positive law.

\section{INFORMATION AS A REGULATORY TOOL}

In this Part I deal with the rise of informational regulation. At least a general understanding of this development is a prerequisite for an understanding of informational standing. In addition, it is worthwhile to have a sense of this important development in the fabric of the modern regulatory state, a development that promises to become all the more central in the coming decade, when there will likely be a great deal of experimentation in this direction. ${ }^{20}$

\section{A. An Overview}

Informational regulation is far from new to American law. At common law, sellers of goods and services face certain obligations of disclosure; thus a failure to convey relevant information may violate the common law of contract or tort. ${ }^{21}$ The New Deal, of course, witnessed a dramatic shift from regulation through common law courts to regulation via administrative agencies, ${ }^{22}$ and disclosure of information became a pervasive regulatory strategy, most obviously through the work of the Securities and Exchange Commission. ${ }^{23}$ But the great modern surge of informational regulation-

${ }^{20}$ This is a bipartisan view. See NEWT GNGRICH ET AL., CONTRACT WITH AMERICA 131-35 (1994) (discussing reforms that would, inter alia, increase information); AL GORE, COMMON SENSE GOVERNMENT: WORKS BETTER AND COSTS LESS (1996) (discussing the Clinton Administration's efforts to restructure the federal government to increase flexibility and reduce rigid regulation).

${ }_{21}$ See McMahon v. Bunn-O-Matic Corp., 150 F.3d 651, 655-56 (7th Cir. 1998) (suggesting that there may be circumstances under which manufacturers must warn consumers "about a surprising feature that is potentially dangerous yet hard to observe," but holding that a coffee manufacturer did not have to provide a detailed warning about the severity of burns potentially caused by hot liquid); RESTATEMENT (THIRD) OF TORTS: PRODUCTS LIABILITY $\S 2$ (1998) ("A product... (c) is defective because of inadequate instructions or warnings when the foreseeable risks of harm ... could have been reduced or avoided by the provision of reasonable instructions or warnings ... and the omission of the instructions or warnings renders the product not reasonably safe."); WILLIAM L. PROSSER, HANDBOOK OF THE LAW OF TORTS 641-82 (4th ed. 1971) (discussing products liability).

${ }^{22}$ See CASS R. SUNSTEIN, AFTER THE RIGHTS REVOLUTION 11-46 (1990) (describing the displacement of the common law by regulatory programs).

${ }^{23}$ See Securities Act of 1933, 15 U.S.C. $\$ 77 \mathrm{~h}, \mathrm{j}$ (1994 \& Supp. III 1997) (establishing disclosure requirements for offerings of securities); Securities Exchange Act of 1934, 15 U.S.C. § 78a-11 (1994 \& Supp. III 1997) (establishing the Securities and Exchange Commission and providing for regulation of securities transactions and exchanges). 
growing out of laws involving health, safety, and the environment-is a post-1960s phenomenon. Mandatory disclosure was a central part of the rights revolution of the 1960 s and 1970 s, and it has become especially prominent in the 1980s and 1990s, largely as an alternative to commandand-control regulation. ${ }^{24}$

Many statutes and regulations now require the disclosure or even the production of information. Some of these are designed to assist consumers in making informed choices; such statutes are meant to be marketenhancing. By contrast, others are designed to trigger political, rather than market, safeguards; such statutes are meant to enhance democratic processes. Of course there is an overlap between the two categories. A statute that requires companies to place "eco-labels" on their products may produce little in the way of consumer response, but shareholders and participants in the democratic process may attempt to punish those whose labels reveal environmentally destructive behavior. Companies will know this in advance, with likely behavioral consequences. The risk of sanctions from shareholders and state legislatures may well produce environmental improvement even without regulation..$^{25}$

Heavily publicized health risks from tobacco represent the most prominent forerunners of more recent measures that attempt to fortify the operations of markets by informing consumers. Thus, mandatory messages about the dangers of cigarette smoking, first set out in 1965 and modified in 1969 and 1984, are, of course, designed to ensure that smokers are aware of the associated risks. ${ }^{26}$ The Food and Drug Administration ("FDA") has long maintained a policy of requiring risk labels for pharmaceutical products. ${ }^{27}$ The Environmental Protection Agency ("EPA") has done the same for pesticides and asbestos. ${ }^{28}$ Congress itself requires warnings on products that

${ }^{24}$ See the discussion of informational strategies in ROBERT V. PERCIVAL ET AL., ENVIRONMENTAL REgULATION: LAW, SCIENCE, AND POLICY 612-27 (2d ed. 1996).

${ }^{25}$ Consider the eco-label required by the European Union. See Council Regulation 880/92 of 23 March 1992 on a Community Eco-Label Award Scheme, 1992 O.J. (L99) 1. See generally Kleindorfer \& Orts, supra note 4.

${ }^{26}$ See Comprehensive Smoking Education Act of 1984, Pub. L. No. 98-474, 98 Stat. 2204 (codified as amended at 15 U.S.C. $\$ \$ 1331-41$ (1994)) (requiring multiple warnings about the health risks associated with smoking); Public Health Cigarette Smoking Act of 1969, Pub. L. No. 91-222, 84 Stat. 87 (1970) (codified as amended at 15 U.S.C. $\$ \S 1331-41$ (1994)) (same); Federal Cigarette Labeling and Advertising Act of 1965, Pub. L. No. 89-92, 79 Stat. 282 (codified as amended at 15 U.S.C. $\$ \$ 1331-1341$ (1994)) (same).

${ }^{27}$ See 21 C.F.R. $\$ 201.57$ (1998) (stating labeling requirements for prescription drugs and insulin).

${ }^{28}$ See 7 U.S.C. \$ 136-136y (1994 \& Supp. III 1997) (referring to environmental pesticide regulations); 15 U.S.C. $\$ \$ 2601-29$ (1994) (listing EPA regulations that require warning labels for products containing polychlorinated biphenyls ("PCBs"), asbestos, or hexavalent chromium, a water treatment chemical, promulgated under the federal Toxic Substances Control 
contain saccharin. ${ }^{29}$ There are numerous other illustrations, but several post- 1980 initiatives are especially striking and deserve brief description by way of illustration and for purposes of understanding the standing question.

In 1983, the Occupational Safety and Health Administration ("OSHA") issued a Hazard Communication Standard ("HCS"), applicable to the manufacturing sector. ${ }^{30}$ In 1986 , the HCS was made generally applicable. ${ }^{31}$ Under the HCS, chemical producers and importers must evaluate the hazards of the chemicals they produce or import; develop technical hazard information for material safety data sheets, and labels for hazardous substances; and, most importantly, transmit this information to users of the relevant substances. All employers must adopt a hazard communication program-one that includes individual training-and inform workers of the relevant risks. ${ }^{32}$

The FDA has also adopted informational strategies. In its most ambitious set of proposals, the FDA required a form of disclosure that affected nearly all food and drink purchased in the United States. The FDA (1) compelled nutritional labeling on nearly all processed foods, including information relating to cholesterol, saturated fat, calories from fat, and fiber; (2) required compliance with government-specified serving sizes; (3) compelled companies to conform to government definitions of standardized terms, including, "reduced," "fresh," "free," and "low"; and (4) allowed health claims only if the claims (a) are supported by scientific evidence and (b) communicate clear and complete information about such matters as fat and heart disease, fat and cancer, sodium and high blood pressure, and calcium and osteoporosis. ${ }^{33}$

Act (TSCA)); 40 C.F.R. $\S 156.10$ (1998) (detailing EPA regulations requiring waming labels on pesticides promulgated under the Federal Insecticide, Fungicide and Rodenticide Act (FIFRA)).

29 See 21 U.S.C. $\$ 343(0)$ (1994) (requiring a warning on products containing saccharin that the sweetener causes cancer in laboratory animals).

${ }^{30}$ See Hazard Communication, 29 C.F.R. $\$ 1910.1200$ (1998). OSHA promulgated a standard requiring

all chemical manufacturers and importers to assess the hazards of chemicals which they produce or import, and all employers having workplaces in the manufacturing division, ... . to provide information to their employees concerning hazardous chemicals by means of hazard communication programs including labels, material safety data sheets, training, and access to written records.

Id.

31 See 52 Fed. Reg. 31,852 (1987) (expanding the scope of the HCS to "cover all employers with employees exposed to hazardous chemicals in their workplaces").

${ }^{32}$ See id. ("Expansion of the scope of the HCS requires non-manufacturing employers to establish hazard communication programs to transmit information on the hazards of chemicals to their employees by means of labels on containers, material safety data sheets, and training programs.").

${ }^{33}$ See 58 Fed. Reg. 2,927 (1993). 
A great deal of recent attention has been given to informational regulation in the particular context of the communications industry. As an alternative to direct regulation, which raises especially severe First Amendment problems, the government might attempt to increase information instead. Thus, the mandatory "V-chip" is intended to permit parents to block programming that they want to exclude from their homes. ${ }^{34}$ The V-chip is supposed to work hand-in-hand with a ratings system. ${ }^{35}$ Similarly, a provision of the 1996 Telecommunications Act (1) requires television manufacturers to include technology capable of reading a program rating mechanism; (2) requires the Federal Communications Commission ("FCC") to create a ratings methodology if the industry does not produce an acceptable ratings plan within a year; and (3) requires that broadcasters include a rating in their signals if the relevant program is rated. ${ }^{36}$ Spurred by this statute, most of the networks generated a system for television ratings that is now in place. ${ }^{37}$ A new set of proposals under current discussion would require broadcasters to make public a set of reports about their public interest activities, including providing free time for political candidates and educational programming. 38

As I have noted, some disclosure statutes are designed to trigger political, rather than market, mechanisms; here consumers are not directly involved. The most famous of these statutes is NEPA. Enacted in 1972, NEPA's principal goal was to require the government to compile and disclose environmentally related information before going forward with any projects having a major effect on the environment. ${ }^{39}$ NEPA does not require the government to give environmental effects any particular weight, nor is there judicial review of the substance of agency decisions. ${ }^{40}$ The pur-

34 See James P. Hamilton, Channeling Violence: The Economic Market For VIOLENT TElevision PROGRAMMIng 289-92 (1998) (discussing the political call for a Vchip);

35 See id. at 289 (noting that the V-chip can block programs which carry ratings).

361996 Telecommunications Act, 58 U.S.C. \$\$ 151-611 (1998); see also HAMILTON, supra note 34 , at 302 (discussing ratings requirements).

37 See HAMILTON, supra note 34, at 304-11 (detailing the development of the television ratings system).

${ }^{38}$ See FINAL REPORT OF THE ADVISORY COMMITTEE ON PUBLIC INTEREST Obligations of Digital television BRoAdcasters: Charting the Digital BROADCASTING FUTURE 45-46 (1998) [hereinafter FINAL REPORT] (calling for "enhanced disclosures of ... public interest programming and activities on a quarterly basis" and other recommendations); Cass R. Sunstein, Private Broadcasters and the Public Interest (1999) (unpublished manuscript) (on file with author).

${ }^{39}$ See Calvert Cliffs' Coordinating Comm., Inc. v. United States Atomic Energy Comm'n, 449 F.2d 1109, 1112 (D.C. Cir. 1971) (noting NEPA's procedural goal).

${ }^{40}$ See Strycker's Bay Neighborhood Council, Inc. v. Karlen, 444 U.S. 223, 227 (1980) (stating that "once an agency has made a decision subject to NEPA's procedural requirements, 
pose of disclosure is principally to trigger political safeguards coming from the government's own judgments or from external pressure. ${ }^{41}$ Hence, any governmental indifference to adverse environmental effects is perfectly acceptable under NEPA. The idea behind the statute is that if the public is concerned, then the government will have to give some weight to environmental effects.

In 1986, Congress enacted an ambitious statute, the Emergency Planning and Community Right-to-Know Act ("EPCRA"). Under this statute, firms and individuals must report to state and local governments the quantities of potentially hazardous chemicals that have been stored or released into the environment. Users of such chemicals must report to their local fire departments the location, types, and quantities of stored chemicals. They must also give information about potential adverse health effects. On the basis of the relevant results, the EPA publishes pollution data about the release of over 300 chemicals from over 20,000 facilities. ${ }^{43}$ This has been an exceptional success story, one that has well exceeded the expectations at the time of the statute's enactment. ${ }^{44}$ A detailed report by the General Accounting Office suggests that EPCRA has had important beneficial effects, spurring innovative, cost-effective programs from the EPA and from state and local governments. ${ }^{45}$

Many other statutes involving health, safety, and the environment fall into this general category. The Animal Welfare Act is designed partly to ensure publicity about the treatment of animals; thus covered laboratories are required to file reports with the government about their conduct, ${ }^{46}$ with the apparent thought that the reports will deter noncompliance and also allow continual monitoring. In addition to its various command-and-control provisions, the Clean Air Act requires companies to create and disclose "risk management plans" involving accidental releases of chemicals, which

the only role for a court is to insure that the agency has considered the environmental consequences").

${ }^{41}$ See id. (noting that NEPA is an "area of discretion of the executive as to the choice of the action").

4242 U.S.C. $\$ \$ 11,001-50$ (1994); see also supra note 5 and accompanying text.

43 See HAMILTON, supra note 34, at 302 (stating these figures for EPA pollution data).

44 See PERCIVAL ET AL., supra note 24, at 624, 626 ("Congress anticipated that the availability of information ... would enable the public to put substantial pressure on companies to reduce emissions.").

45 See General Accounting Office, Toxic Chemicals, Report to the Congress (1991) [hereinafter GAO Report].

46 Animal Welfare Act, 7 U.S.C. $\$ \S 2131-59$ (1994). 
must include a worst case scenario. ${ }^{47}$ The Safe Drinking Water Act was amended in 1996 to require annual "consumer confidence reports" to be developed and disseminated by community water suppliers. ${ }^{48}$ Statutes governing mortgages, crime, discrimination, sexual violence, and medical care also seem partly committed to the idea that "sunlight is . . . the best of disinfectants"; 49 thus, they require covered institutions to compile reports about their conduct and compliance with applicable law. ${ }^{50}$ As noted, FECA requires political committees to disclose a great deal of information about their activities. In the same category is a proposed code for television broadcasters, designed partly to ensure publicity about the public service activities of various stations. Its goal is to ensure more in the way of such activities indirectly, and simply by virtue of the fact that there will be a public accounting. ${ }^{51}$

For an overview, consider the following table:

4742 U.S.C. $\$ 7412(r)(1994)$.

4842 U.S.C. $\$ 300 \mathrm{~g}-3(\mathrm{c})(4)$ (1994).

49 The phrase comes from LoUIS D. BRANDEIS, OTHER PEOPLE'S MONEY AND HOW THE BANKERS USE IT 62 (Torchbook ed. 1967).

${ }^{50}$ See, e.g., Home Mortgage Disclosure Act of 1975 (HMDA), 12 U.S.C. $\$ \S 2801-10$ (1994) (requiring banks to maintain records of where they make mortgage loans and to make such records available to the public); Community Reinvestment Act of 1977 (CRA), 12 U.S.C. $\$ \S 2901-07$ (1994) (subjecting banks to detailed reporting requirements and rating the banks based on the extent to which they serve their community); Crime Awareness and Campus Security Act of $1990 \S 204(\mathrm{a}), 20$ U.S.C. $§ 1092(f)(1)-(6)$ (1994) (requiring that colleges develop policies to encourage the prompt reporting of crimes to police and college officials); Higher Education Amendments of 1992 § 486(c)(1)-(2), 20 U.S.C. \& 1092(f)(1)(F), (f)(7) (1994) (requiring that colleges compile and report statistics on listed crimes including sexual assault, and requiring that colleges promulgate and enforce policies against sexual assault); Federal Water Pollution Control Act, 33 U.S.C. $\$ \$ 1319,1342,1369$ (1994) (requiring permit holders to sample their discharges and then submit the results in the form of dischargemonitoring reports ("DMRs") to the proper authority; these DMRs are made available to the public).

51 See FINAL REPORT, supra note 38, at 45-46 (discussing proposed disclosures of public interest activities). 
Table 1. Examples of Informational Regulation

\begin{tabular}{|c|c|c|}
\hline & $\begin{array}{l}\text { Trigger Market } \\
\text { Reactions }\end{array}$ & $\begin{array}{l}\text { Trigger Political } \\
\text { Reactions }\end{array}$ \\
\hline $\begin{array}{c}\text { Duties } \\
\text { Imposed on } \\
\text { Private Sector }\end{array}$ & $\begin{array}{l}\text { Tobacco warnings } \\
\text { legislation } \\
\text { - Nutrition regulation } \\
\text { - Warnings for television } \\
\text { programming } \\
\text { - Hazardous materials } \\
\text { warning regulation } \\
\text { - Telecommunications } \\
\text { Act of } 1996 \text { (ratings } \\
\text { system) } \\
\end{array}$ & $\begin{array}{l}\text { EPCRA (annual } \\
\text { reports) } \\
\text { - Proposed broadcasters } \\
\text { code } \\
\text { - Animal Welfare Act } \\
\text { - Clean Air Act's "risk } \\
\text { management plans" } \\
\text { - Age Discrimination Act }\end{array}$ \\
\hline $\begin{array}{l}\text { Duties } \\
\text { Imposed on } \\
\text { Government }\end{array}$ & $\begin{array}{l}\text { Warnings about the use } \\
\text { of drugs }\end{array}$ & $\begin{array}{l}\text { - EPCRA (Toxic Release } \\
\text { Inventory) } \\
\text { - NEPA } \\
\text { - Safe Drinking Water } \\
\text { Act } \\
\text { - FECA }\end{array}$ \\
\hline
\end{tabular}

\section{B. Rationale}

Why has information disclosure become such a central regulatory tool? There are several answers. For various reasons, a market failure may come in the form of an inadequate supply of information. ${ }^{52}$ Because information is generally a public good ${ }^{53}$-something that if provided to one is also provided to all or many-workers and consumers may attempt to free ride on the efforts of others, resulting in too little information being provided. For this reason, compulsory disclosure of information can provide the simplest response to the relevant market failure.

52 See OGUS, supra note 4, at 121-23 (1994) (discussing information deficits).

53 Of course, it is possible to give information more "private good" characteristics, and innovative approaches can be expected in the next decade. Consider, for example, fees for access to information on the Internet or the subscription-based Consumer Reports. Neither of these approaches converts information into a private good, but both reduce the range of people who may, without high cost, have access to it. Thus, it is possible to imagine a range of approaches that would diminish the cost of access for some or many, while increasing it, or holding it constant, for others. 
It is increasingly recognized that information is often a far less expensive and more efficient strategy than command-and-control, which consists of rigid mandates about regulatory ends (a certain percentage reduction in sulfur dioxide, for example), regulatory means (a technological mandate for cars, for example), or both. ${ }^{54}$ A chief advantage of informational regulation is its comparative flexibility. If consumers are informed of the salt or sugar content of foods, they can proceed as they wish, trading off various product characteristics however they see fit. If workers are given information about the risks posed by their workplace, then they can trade safety against other possible variables (such as salary, investments for children or retirement, and leisure). ${ }^{55}$ From the standpoint of efficiency, information remedies can be better than either command-and-control regulation or reliance on unregulated markets alone.

From the democratic point of view, informational regulation also has substantial advantages. A well-functioning system of deliberative democracy requires a certain degree of information, so that citizens can engage in their monitoring and deliberative tasks. Subject as they are to parochial pressures, segments of the government may have insufficient incentives to disclose information on their own; consider FOIA or FECA, where the selfinterest of the government or private groups may press in the direction of too little disclosure. A good way to enable citizens to oversee government action and also to assess the need for less, more, or different regulation, is to inform them of both private and public activity. The very fact that the public will be in a position to engage in general monitoring may well spur desirable outcomes.

EPCRA is the most obvious example here. Sharp, cost-effective, and largely unanticipated reductions in toxic releases have come about without anything in the way of direct regulation. ${ }^{56}$ This approach appears to be emerging as the wave of the future. ${ }^{57}$ In the area of broadcasting, it is possible to hope that disclosure of public interest programming, and the mere need to compile the information each year, will increase educational and public affairs programming without involving government mandates at all..$^{58}$

54 See BREYER, supra note 4, at 161-64 (analyzing disclosure as an alternative regulatory regime); OGUS, supra note 4 , at $121-49$ (explaining the less interventionist strategy of information regulation).

55 See Cass R. Sunstein, Free Markets and Social Justice 327-28 (1997) (discussing efficiency and information).

${ }^{56}$ See PERCIVAl ET AL., supra note 24, at 612-16 (discussing the efficacy of informational approaches to toxic substance regulation).

57 See supra text accompanying notes 4-10.

58 See HAMILTON, supra note 34, at 302 (discussing informal governmental attempts to increase educational programming). 
A primary virtue of informational regulation is that it triggers political safeguards and allows citizens a continuing oversight role-one that is, in the best cases, largely self-enforcing.

\section{Policies and Prospects}

None of this is to say that informational regulation is always desirable. Under imaginable assumptions such regulation will be inferior to commandand-control regulation and to reliance on markets unaccompanied by disclosure requirements. There are two problems with informational strategies. First, providing information may be expensive, sometimes costing more than it is worth. Second, the provision of information is sometimes ineffectual, or even counterproductive.

Consider, for example, the fact that the government estimated the cost of the FDA disclosure rules as " $\$ 1.7$ billion over twenty years." The president of the National Food Processors Association claimed that the firstyear costs alone would exceed $\$ 2$ billion. ${ }^{60}$ In either case, the cost is significant, and an important question is what improvements-in terms of reduced mortality or morbidity-are produced in return. OSHA's hazard communication policy is estimated to save 200 lives per year-a large number-but at an annual cost of $\$ 360$ million. ${ }^{61}$ The expenditure per life saved is therefore $\$ 1.8$ million. This is far better than a large number of regulations, and is probably an amount well worth spending; but it is more than many agencies spend for life-saving regulations. ${ }^{62}$ The OSHA rule does not stand out as a means of saving lives especially cheaply. ${ }^{63}$ (Of course there

59 Nancy Ryan \& Linda M. Harrington, FDA Offers New Rules on Food Labels, Claims, CHI. TRIB., Nov. 7, 1991, at 2.

${ }^{60}$ See id.

61 These figures come from John F. Morrall III, A Review of the Record, 10 REgULATION 25, 30 (Nov./Dec. 1986), which was criticized in Lisa Heinzerling, Regulatory Costs of Mythic Proportions, 107 YAle L.J. 1981, 1999-2000 (1998).

${ }^{62}$ See W. KiP Viscusi, Fatal TRadeoffs: Public and Private Responsibilities FOR RISK 264 (1992).

${ }^{63}$ When informational strategies are costly, there are two possible responses from the government. The first is to do nothing. If the savings - in terms of health, life, and informed choice-are relatively low, then costly strategies, even informational ones, make little sense. There will, therefore, be circumstances in which a government remedy for an absence of information is unwarranted.

The second possibility is to impose a regulatory strategy rather than to require disclosure. By a regulatory strategy I mean a mandatory outcome, such as a flat ban on the materials in question, or governmental specification of a particular outcome, as in a mandated maximum level of carcinogens in the workplace. Sometimes the regulatory strategy will be cheaper because the price of disclosing information - changing packaging and so forth-is so high. This is likely to be the right response when most or all people would respond to the information in the same way. In that case, it is unnecessary to provide information, and better simply to dic- 
are likely to be large morbidity and other gains that are not captured in the "lives saved" number.)

Even when informational strategies are not prohibitively expensive, they may be ineffectual and thus have low benefits; they may even be counterproductive. This is so for various reasons, and here a great deal more work remains to be done. People have a limited ability to process information. $^{64}$ They have a notoriously difficult time thinking about lowprobability events. Sometimes people discount such events to zero; sometimes they treat them as much more dangerous than they actually are. If people are told, for example, that a certain substance causes cancer, then they may think that it is far more dangerous than it is in fact. ${ }^{65}$ But some carcinogenic substances pose little risk of cancer. There is also a pervasive risk of "alarmist bias," as frightening information is more salient and potent than comforting information, regardless of what is true. ${ }^{66}$

For example, California's Proposition 65, an initiative designed to promote citizen awareness of risk levels, requires warnings for exposure to carcinogens. ${ }^{67}$ At first glance, the requirement seems entirely unexceptionable, indeed an important advance. But it has in some ways been counterproductive. Consumers appear to think that twelve of every 100 users of a product with the required warning will die from cancer, an estimate that exceeds reality by a factor of 1000 or more. ${ }^{68}$ With respect to information, less may be more. If information is not provided in a clear and usable form, it may actually make people less knowledgeable than they were before, producing overreactions, or underreactions, based on an ability to understand what the information actually means. People also face a pervasive risk of "information overload," causing consumers to treat a large amount of information as

tate an outcome that, by hypothesis, is generally or almost universally preferred. For an especially dangerous substance, one that reasonable people would choose not to encounter, a flat ban is appropriate.

64 See JUDGMENT UNDER UNCERTAINTY: HeURISTICS AND BIASES (Daniel Kahneman et al. eds., 1982); Christine Jolls et al., A Behavioral Approach to Law and Economics, 50 STAN. L. REV. 1471, 1533-37 (1998) (discussing how simply providing information "is not enough").

65 See W. KIP VISCUSI, PRODUCT-RISK LABELING: A FEDERAL RESPONSIBILITY 11-16 (1993) (analyzing the results of Califomia's Proposition 65); W. KIP VISCUSI, RATIONAL RISK POLICY 5 (1998) (suggesting that "[i]ndividual risk perceptions are often in error").

${ }^{66}$ See W. Kip Viscusi, Alarmist Decisions with Divergent Risk Information, 107 ECON. J. $1657,1666-67$ (1997) ("[T] he fear of the worst case scenario receives greater weight than does the low risk assessment.").

${ }^{67}$ See PERCIVAL ET AL., supra note 24, at 616-21 (describing California's approach to the information problem).

${ }^{68}$ See W. Kip Viscusi, Predicting the Effects of Food Cancer Risk Warnings on Consumers, 43 FOOD DRUG COSM. L.J. 283, 288 (1988) (finding that "individuals have a difficult time in processing refined distinctions between very miniscule probabilities"). 
equivalent to no information at all. ${ }^{69}$ Certainly this is true when disclosure campaigns are filled with details that cannot be processed easily.

With respect to industry responses, companies may respond to certain disclosure requirements by refusing to provide information at all (if this is an available option). The result will be the removal from the market of information that is useful overall. If industry responds to a requirement of evidentiary support for scientific claims with mere "puffing," then consumers may have less information than they did to begin with. If advertisers must conduct extensive tests before they are permitted to make claims, then they will be given a strong incentive to avoid making claims at all. ${ }^{70}$

There is a further problem: optimistic bias. ${ }^{71}$ People often believe themselves to be immune from risks that they acknowledge are significant and real with respect to others. About $90 \%$ of people believe that they are above-average drivers, less likely than others to be involved in automobile accidents. ${ }^{72}$ In one study, $97 \%$ of those surveyed ranked themselves as average or above average in their ability to avoid both bicycle and power mower accidents. ${ }^{73}$ If most people think that the information does not apply to them, disclosure requirements may have little effect.

Disclosure strategies may also have disproportionately little effect on people who are undereducated, elderly, or poor. If this is so, the disadvantaged may continue to face the risks that informational disclosure strategies are aimed to counteract (at least if market forces fail to induce general changes from producers). ${ }^{74}$ And when risks are placed on outsiders who are

69 See Jacob Jacoby et al., Corrective Advertising and Affirmative Disclosure Statements: Their Potential for Confusing and Misleading the Consumer, 46 J. MARKETING 61, 70 (1982) (describing how the language used in remedial statements designed to correct misleading advertising messages may be more confusing to the consumer than the advertising message itself).

${ }^{70}$ See Richard Craswell, Interpreting Deceptive Advertising, 65 B.U. L. REv. 658, 71925 (1985) (noting the various incentives that sellers have to not disclose useful information).

71 See Christine Jolls et al., A Behavioral Approach to Law and Economics, 50 STAN. L. REV. 1471, 1524-27 (1998) (describing optimistic bias as "[a] common feature of human behavior" where "[p]eople tend to think that bad events are far less likely to happen to them than to others").

${ }^{72}$ See Shelley E. TAYlor, Positive Illusions: CREATIVE SELF-DeCEPTION AND THE HEALTHY MIND 10-11 (1993).

${ }^{73}$ See id. at 116.

74 See George W. Schucker et al., The Impact of the Saccharin Warning Label on Sales of Diet Soft Drinks in Supermarkets, 2 J. PUB. POL'Y \& MARKETING 46, 54-56 (1983) (finding no change in diet soft drink sales in poor, undereducated areas after the FDA added warning labels). 
not in a contractual relationship with the wrongdoer, ${ }^{75}$ information may do little good, because the outsiders are not in a position to extract a higher price in return for the relevant risk, and may in fact be unable to do anything about it. ${ }^{76}$

These points should be taken as cautionary notes, and not as suggestions that informational regulation is ill advised. Whether informational regulation is preferable to complete reliance on markets, or instead to regulation through command-and-control or through economic incentives, depends on the details. Certainly there is reason, in both theory and practice, to think that informational regulation is the best approach in many contexts. ${ }^{77}$ The most promising setting involves a market failure in the provision of information and reason to believe that information can be provided in such a way as to be understandable to the people who receive it.

\section{Why Suits? Why Citizen Suits?}

As we will see, Congress sometimes explicitly authorizes citizen suits to ensure disclosure of information. Where Congress is not explicit, inferences must be drawn about legislative instructions; the Administrative Procedure Act ("APA") or some other source of law may or may not be read to allow apparent outsiders to bring suit to require disclosure. This possibility leaves an obvious question. Why does Congress give standing to citizens or others to allow them to use courts to require government, or regulated parties, to disclose information? ${ }^{78}$

The simplest answer is connected to the reason for statutes requiring information disclosure in the first instance. Both agencies and private companies often have powerful incentives to withhold information, and suits can serve both as an ex ante deterrent and as an ex post corrective to an unlawful failure to disclose. In the face of disclosure requirements, government failure may mimic market failure, and a right to bring suit might provide

75 The notions of "outsiders" and "wrongdoers" are of course pre-Coasian. See RONALD H. COASE, THE FIRM, THE MARKET, AND THE LAW 95-156 (1988) (discussing the reciprocal and interactive nature of harms). I use the terms to build on common understandings.

76 See BREYER, supra note 4, at 23 (discussing how information is an inadequate response to extemalities); OGUS, supra note 4, at 310 (same).

77 See the suggestive discussion in JAMES T. HAMLTON, CHANNELING VIOLENCE: THE ECONOMIC MARKET FOR VIOLENT TELEVISION PROGRAMMING 310 (1998), finding that "information provision offers a way to reduce exposure of children to violent programming while allowing adult views to consume what they wish," and MAGAT \& VISCUSI, supra note 4, at 49, discussing the advantages of informational regulation in the hazard warning context, in which the government seeks to reduce accident and health risks.

${ }_{78}$ As noted, there is a separate question about the actual origins of the relevant law; the answer to that question likely will depend on the constellation of relevant interest groups. 
some help. The incentive not to disclose takes multiple forms. People may not want to disclose because of the sheer economic burden of doing so in the first instance. It can be quite costly to compile and disseminate the relevant reports. Consider the large expense involved in producing an EIS, ${ }^{79}$ as well as other paperwork requirements that may impose substantial burdens. ${ }^{80}$

In addition, both private and public agencies may have an incentive not to disclose because of the qualitatively diverse problems, and costs, that may follow disclosure. The market may well punish bad news via decreased sales or (perhaps in consequence) decreased stock prices; the punishment may be mild, optimal, or excessive and alarmist, ${ }^{81}$ and it can be hard to predict in advance. A cereal company that discloses the nutritional content of its foods may find itself with much fewer purchasers; a company that discloses workplace risks may have to increase wages or cut back production. An agency and affected developers may resist compiling an EIS because once the statement is made public, the project itself will be in jeopardy. The perception of jeopardy may impose costly delays and eventually development may be blocked entirely-a far from uncommon result of the EIS process. ${ }^{82}$ So too, a political organization that discloses its financial backers may find itself far less influential.

These incentives not to disclose may be especially hard to counteract in light of the fact that information is often a public good. ${ }^{83}$ As noted above, the benefits of disclosure are often obtained by many people, whereas the costs of ensuring disclosure are borne (at least in the short run) by one or a few. In these circumstances, it is possible that with market ordering, or even a law on the books, few or none will bother to take the necessary steps-economic, political, or otherwise-to counteract the unlawful withholding of information. Thus, the economic and political markets may underproduce disclosure, even in the face of a law that mandates it.

79 Millions of dollars are appropriated each year for federal oversight alone. See WILLIAM RODGERS, ENVIRONMENTAL LAW 806 (1994).

${ }^{80}$ Hard data are difficult to find, but the Paperwork Reduction Act of 1980,44 U.S.C. $\$ \S$ 3501-20 (1994 \& Supp. II 1996), was a clear response to perceived expenses.

81 There is a real possibility of an alarmist reaction, producing excessive punishment; alarmist information is especially salient and hence memorable, and people might read nonalarmist information in an alarming way. See Timur Kuran \& Cass R. Sunstein, Availability Cascades and Risk Regulation, 51 STAN. L. REV. (forthcoming Apr. 1999); Viscusi, supra note 66 , at 1668 (concluding that people overvalue risk, overreact to highly publicized risks, and "place considerable weight on the risk information provided to them").

82 See PERCIVAL ET AL., supra note 24, at 1060-65 (discussing the adequacy of the EIS approach).

${ }^{83}$ See BREYER, supra note 4, at 26 (discussing the public good aspects of information); OGUS, supra note 4, at 121-26 (same). 
Congress may offer a broad grant of standing--perhaps even to citizens generally-so as to counteract the relevant incentives. The hope is that some plaintiff, whether altruistic or self-interested, will take steps to ensure the availability of information. FOIA is the most obvious example. The grant of the power to obtain information, and to litigate, to "any person" 84 operates to inform agencies that there will be ready judicial review of any denial of a FOIA request, a factor that should make agencies less likely to engage in unlawful denials. In any case, such denials can and often will be corrected if they are unlawful. Or Congress may decide that citizens generally can bring suit against the FEC to ensure compliance with federal campaign laws, believing that this mechanism will deter violations of a law central to the electoral process. A general grant of standing may help to remedy the problems created by the relevant incentives and the public-good character of information, for there may be someone, out of a large group of potential beneficiaries, who is willing to bear the costs of a lawsuit. As we shall see, Akins itself is a prime example. ${ }^{85}$

None of this is to say that a grant of informational standing is a good idea. Lawsuits can be expensive; they also can be diversionary and even frivolous. With respect to information, a grant of standing to all citizens may divert an agency from its preferred course of action and can make sensible priority-setting extremely difficult. It even may involve a kind of private conscription of public resources ${ }^{86}$ in a way that undermines a fully democratic effort, by the agency involved, to allocate its limited resources to the most serious problems. If all citizens can bring suit against the FEC to require it to regulate all groups that any citizen would like to see treated as "political committees," then the FEC may have to spend all of its time defending itself in court. If any agency definition of "animals" can prompt a federal action by some citizen asking the government to expand its definition, ${ }^{87}$ the government may have fewer resources to enforce the Animal Welfare Act. Alternatively, the mere risk of a citizen suit may lead the agency to an outcome that it believes is undesirable, and that perhaps is, in

84 U.S.C. $§ 552$ (1994 \& Supp. III 1997).

${ }^{85}$ See infra Part II (discussing the Court's holding and analysis in Akins).

${ }^{86}$ See Michael S. Greve, Private Enforcement, Private Rewards: How Environmental Citizen Suits Became an Entitlement Program, in ENVIRONMENTAL POLITICS: PUBLIC Costs, PrIVATE Rewards 105, 108-10 (Michael S. Greve \& Fred L. Smith, Jr. eds., 1992) (discussing the increase in private enforcement actions under the Clean Water Act as a result of the ease in bringing such actions, the EPA's desire to settle the suits, and the subsequent transfer of settlement payments from the agency to private environmental groups).

87 See Animal Legal Defense Fund, Inc. v. Espy, 23 F.3d 496, 496 (D.C. Cir. 1994) ("Animal welfare groups and two individuals brought suit challenging [a] regulation promulgated by [the] Department of Agriculture that failed to include birds, rats and mice as 'animals' within the meaning of [the] Federal Laboratory Animal Welfare Act (FLAWA)."). 
fact, undesirable. From the agency's point of view, if the suit can be avoided by choosing a certain route, why not choose that route, even if the suit might be unsuccessful and even if the problem at hand does not deserve agency attention?

These points are sufficient to show that it cannot be decided, in the abstract, whether a grant of informational standing is or is not desirable. The answer depends on a range of empirical issues-the likely performance, without lawsuits, of the agency and the private sector; the cost of any lawsuits; the effects of lawsuits on the agency's capacity for priority-setting; and the effects of lawsuits on the agency's substantive regulation. It would be highly desirable to obtain a great deal more information on these points.

\section{E. Standing Puzzles and Problems}

Before Akins, the law governing standing to obtain information was in considerable disarray, probably in even more disarray than the law of standing generally. The most serious question was how the "injury in fact" requirement ${ }^{88}$ should operate in cases involving a deprivation of access to information. The Supreme Court has held that a public interest group, consisting of citizens, suffered an injury in fact when the group was deprived of information that was required to be disclosed under the statute governing federal advisory committees. ${ }^{89}$ The Court has also held that deprivation of information concerning available housing constituted a sufficiently "specific injury" to establish injury in fact. ${ }^{90}$ Lower courts have uniformly upheld the general grant of standing under FOIA, but without providing a clear rationale for doing so. ${ }^{91}$

Outside of the FOIA context, the leading case is Lujan v. Defenders of Wildlife, ${ }^{92}$ which invalidated a congressional grant of citizen standing and suggested that citizens could not bring suit unless a "concrete" and "par-

${ }^{88}$ See, e.g., Lujan v. Defenders of Wildlife, 504 U.S. 555, 561 (1992) (establishing that the "irreducible constitutional minimum of standing contains three elements," one of which is that the "plaintiff must have suffered an "injury in fact").

${ }^{89}$ See Public Citizen v. Department of Justice, 491 U.S. 440, 449 (1989) (rejecting the department's argument that the plaintiff did not allege sufficient injury so as to confer standing).

90 See Havens Realty Corp. v. Coleman, 455 U.S. 363, 374 (1982).

91 See Reporters Comm. for Freedom of the Press v. Sampson, 591 F.2d 944, 945 (D.C. Cir. 1978) (granting standing to plaintiffs seeking access to Richard Nixon's presidential materials through FOIA); Skolnick v. Parsons, 397 F.2d 523, 524-25 (7th Cir. 1968) (holding that the plaintiff had standing to bring an action to compel the President's Commission on Law Enforcement and Administration of Justice to release a specific report).

92504 U.S. at 571-72 (1992) (holding that the respondents lacked standing to seek judicial review of Section 7(a)(2) of the Endangered Species Act of 1973). 
ticularized" interest was at stake. ${ }^{93}$ This idea seemed to suggest that a widely generalized injury, of the sort often invoked by information-seeking plaintiffs, would not be a sufficient basis for standing. Thus, the injury in fact requirement, after Lujan, appeared to merge with the ban on standing for those invoking generalized grievances, and to have created serious adverse consequences for those seeking informational standing. ${ }^{94}$ At the same time, lower courts generally agreed that withholding information to which a plaintiff had a legal right was sufficient to create a legal injury for purposes of Article III. ${ }^{95}$ But a complex set of rulings from the D.C. Circuit suggested that a plaintiff whose injury was widely shared would be held to not have standing under the "zone of interests" test. ${ }^{96}$

It seemed clear that the Court's recent standing cases were on a kind of collision course with a number of statutes, including FOIA and FECA, which gave standing to citizens generally. It was against this background that the Court decided Akins.

\section{WHAT THE COURT SAID}

The American Israel Public Affairs Committee ("AIPAC") may or may not be a "political committee" within the meaning of FECA. If AIPAC is a political committee, then it is subject to a range of legal restrictions, involving, for example, statutory limits on the amount that it can contribute to a candidate for political office. ${ }^{97}$ More importantly for the particular purposes of informational standing, FECA imposes a number of record-keeping and disclosure requirements on all political committees. ${ }^{98}$ These requirements are designed to expose a range of political activities to public view. As a result, such committees must register with the FEC; keep names and addresses of contributors; record the purpose and amount of disbursements; and file annual reports to the FEC which include lists of donors giving more than $\$ 200$ per year, contributions, expenditures, and disbursements. ${ }^{99}$ A series of complex provisions define "political committee." The statute also

93 Id. at 560.

94 See Federal Election Comm'n v. Akins, 118 S. Ct. 1777, 1791 (1998) (Scalia, J., dissenting) (questioning the majority's suggestion that abstract interests "go hand in hand" with those which are unduly shared).

95 See infra notes 110-12 and accompanying text (discussing the requirements for a legal injury).

${ }^{96}$ See infra notes 212-13, 218-19, 225-27 and accompanying text (discussing the zone of interests test).

97 See 2 U.S.C. $\$ \S 432-34$ (1992).

98 See id. (codifying registration requirements for political committees).

99 See id. 
provides that "any person who believes a violation of this Act ... has occurred, may file a complaint with the Commission."100 It adds that "[a]ny party aggrieved by an order of the Commission dismissing a complaint filed by such party ... may file a petition"101 to seek review of the dismissal of the complaint.

In 1997, a number of voters attempted to persuade the FEC to treat AIPAC as a political committee. ${ }^{102}$ Their evident motivation was political disagreement with AIPAC. They also believed that AIPAC was involved in campaign activities and that the FEC had behaved unlawfully in failing to engage in regulation and in failing to require disclosure of AIPAC's relevant activities. ${ }^{103}$ After extended deliberation, the FEC concluded that it did not consider AIPAC to be such a committee, because "the Act's definition of 'political committee' includes only those organizations that have as a 'major purpose' the nomination or election of candidates." 104 AIPAC was an "issue-oriented lobbying organization, not a campaign-related organization." 105 Disagreeing with the FEC's judgment, the voter-plaintiffs then filed suit to seek review of the complaint, claiming that they were "aggrieved" and therefore statutorily authorized to bring suit. The FEC responded by asserting, among other things, that the voters lacked standing in their capacity as citizens and that the suit should therefore be dismissed.

In Akins, the Supreme Court held that the voters had standing because of their interest in obtaining the relevant information about AIPAC. ${ }^{106}$ The analysis came in four parts. First, the Court said that there was no problem with "prudential standing." 107 Congress itself had granted standing to "[a]ny party aggrieved," 108 and any prudential limits had been overcome by statute and were therefore inapplicable. ${ }^{109}$

100 Id. $\S 437 \mathrm{~g}(\mathrm{a})(1)$.

101 Id. $\$ 437 \mathrm{~g}(\mathrm{a})(8)(\mathrm{A})$.

102 See Federal Election Comm'n v. Akins, 118 S. Ct. 1777, 1781-82 (1998) (discussing the efforts of a group of voters from which this case arose).

${ }^{103}$ See id. (noting that voters had "views often opposed to those of AIPAC").

104 Id. at $1782-83$.

${ }^{105} \mathrm{Id}$.

106 See id. at 1784 (holding that plaintiffs suffered a "genuine "injury in fact" since they could not obtain information concerning AIPAC donors and contributions).

107 Id. at 1783 .

108 Id.

109 In his dissent, Justice Scalia disagreed on this point, suggesting that there was a difference between a "party" who could file a complaint with the FEC and a "party aggrieved" who could bring suit. See id. at 1789-90 (Scalia, J., dissenting) (calling the majority's interpretation of an aggrieved party "too much of a stretch"). 
Second, the plaintiffs suffered injury in fact, and hence the statutory grant of standing to citizens was constitutional. ${ }^{110}$ The injury "consists of their inability to obtain information-lists of AIPAC donors ... and campaign-related contributions and expenditures-that, on respondents' view of the law, the statute requires that AIPAC make public." 111 The Court added that there was "no reason to doubt their claim that the information would help them ... to evaluate candidates for public office, especially candidates who received assistance from AIPAC, and to evaluate the role that AIPAC's financial assistance might play in a specific election."112 This injury was sufficiently "concrete and particular" for purposes of Article III.

The Court faced a possible obstacle to this conclusion in United States v. Richardson. ${ }^{113}$ There, a plaintiff bringing suit principally as a taxpayer sought information involving the expenditures of the Central Intelligence Agency ("CIA"), which, in his view, had to be made public under the Accounts Clause of the Constitution. The Court denied standing. ${ }^{114}$ As the Akins Court explained, this was because there was no "logical nexus" between the plaintiff's taxpayer status and the claimed failure of Congress to require a more detailed report of CIA expenditures. ${ }^{115}$ In Akins, by contrast, "there is a statute which, as we have previously pointed out[] ... does seek to protect individuals ... from the kind of harm they say they have suffered." Under FECA, the "logical nexus' inquiry" in Richardson was thus entirely irrelevant. ${ }^{117}$ In a crucial passage, the Court added that Akins was a case involving not taxpayer standing, but voter standing. If Richardson had involved voter standing, the question would have arisen whether the Constitution's "general directives" allowed for enforcement through lawsuits brought by private persons. The answer to that question "(like the answer to whether there was taxpayer standing in Richardson) would have rested in significant part upon the Court's view of the Accounts Clause.", 118

At this point, the Court turned to the third standing question: whether standing was lacking because the injury was a "generalized grievance,"

${ }^{110}$ See id. at 1784 (stating that a plaintiff suffers an injury in fact when the plaintiff" fails to obtain information which must be publicly disclosed pursuant to a statute").

111 Id.

112 Id.

113418 U.S. 166, 179-80 (1974) (holding that respondents lacked standing because they had nothing more than "generalized grievances" and had not suffered an actual injury).

114 See id. at 171.

115 Akins, 118 S. Ct. at 1784; see also Richardson, 418 U.S. at 175.

116 Akins, $118 \mathrm{~S}$. Ct. at 1785 .

117 Id.

${ }^{118}$ Id. 
shared by all or most citizens. The Court acknowledged that previous decisions suggested "that where large numbers of Americans suffer alike, the political process, rather than the judicial process, may provide the more appropriate remedy for a widely shared grievance." 119 Indeed, in some cases, including Richardson itself, the Court suggested that Article III might be an obstacle to a suit by plaintiffs whose injuries were widely shared. ${ }^{120}$ But the Court concluded that with an express congressional grant of standing, the generalized character of the grievance here was no obstacle, because the limitation was prudential in character. In its key step, the Court distinguished between injuries that are widely shared and injuries that are "abstract and indefinite." An abstract injury-such as an injury "to the interest in seeing that the law is obeyed"121 — would not allow for standing. By contrast, a concrete but widely shared injury would suffice for purposes of Article III. "Thus the fact that a political forum may be more readily available where an injury is widely shared (while counseling against, say, interpreting a statute as conferring standing) does not, by itself, automatically disqualify an interest for Article III purposes." Court "obvious" for cases involving the same common law injury, as in a mass tort or an "interference with voting rights."123 "We conclude that similarly, the informational injury at issue here, directly related to voting, the most basic of political rights, is sufficiently concrete and specific such that the fact that it is widely shared does not deprive Congress of constitutional power to authorize its vindication in federal courts."

The fourth and final standing issue involved redressability. Would the plaintiffs' injury be remedied by a decree in their favor? The FEC urged that even if it agreed with the plaintiffs on the law, it may have exercised its statutory discretion so as not to require AIPAC to produce the information. Thus the plaintiffs' injury might not be redressed by a decree in their favor. The Court answered with an analogy: "Agencies often have discretion about whether or not to take a particular action. Yet those adversely affected by a discretionary agency decision generally have standing to complain that the agency based its decision upon an improper legal ground."125 The Court explained that it is typical to remand a case after a judicial judg-

119 Id.

120 See, e.g., Lujan v. Defenders of Wildlife, 504 U.S. 555, 576-78 (1992) (suggesting that Article III may prevent a citizen with only generalized grievances from bringing suit).

121 Akins, $118 \mathrm{~S}$. Ct. at 1786.

$122 \mathrm{Id}$

$123 \mathrm{Id}$

$124 \mathrm{Id}$.

125 Id. (citing Abbott Lab. v. Gardner, 387 U.S. 136, 140 (1967)). 
ment, even though the agency may end up doing the same thing after the remand. This familiar practice was sufficient to justify a conclusion that the plaintiffs had met the redressability requirements.

Justice Scalia's dissenting opinion was rooted in a concern that the legal provision in FECA "is an extraordinary one, conferring upon a private person the ability to bring an Executive agency into court to compel its enforcement of the law against a third party."126 His principal argument invoked Richardson, which, in Justice Scalia's view, held that in order to have standing, each plaintiff's harm must be "particularized," in the sense that it affects him "in a personal and individual way." I27 In a mass tort, each person suffers "a particularized and differentiated harm"; but in this case, as in Richardson, the harm caused to the plaintiff is "precisely the same as the harm caused to everyone else." 128 The requirement of a particularized harm is also based on a sound understanding of Article II, which gives the Executive, not the courts, the responsibility to "take Care that the Laws be faithfully executed." 129

Justice Scalia complained that the logic of the Court's opinion is that "it is within the power of Congress to authorize any interested person to manage (through the courts) the Executive's enforcement of any law that includes a requirement for the filing and public availability of a piece of paper." ${ }^{, 130}$ The result of allowing suits in cases like these is to produce "a shift of political responsibility to a branch designed not to protect the public at large but to protect individual rights."131 This result would violate both $\mathrm{Ar}$ ticle III and Article II. ${ }^{132}$

\section{EVALUATING AKINS: INFORMATIONAL STANDING AS A QUESTION OF STATUTORY LAW}

I now turn to an evaluation of the Court's principal conclusions. The unifying theme is that with respect to information, and perhaps more generally, the Court has rooted the standing question firmly in Congress's instructions. Whether a plaintiff has standing depends on what the relevant

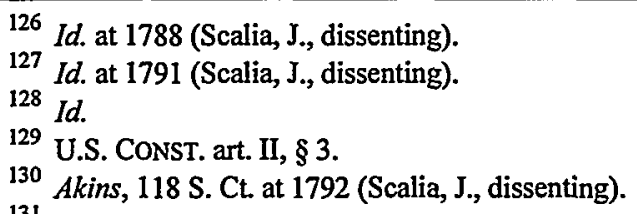

131 Id. This point amounts to a one-sentence summary of Justice Scalia's influential essay on standing. See Antonin Scalia, The Doctrine of Standing as an Essential Element of the Separation of Powers, 17 SUFFOLK U. L. REV. 881 (1983).

${ }^{132}$ See Akins, $118 \mathrm{~S}$. Ct. at 1791-92 (Scalia, J., dissenting) (arguing that the statute unconstitutionally transfers executive power under Article II to Article III courts). 
statute says. For both the "injury in fact" and generalized grievance issues, the foundation for the Court's conclusion is that Congress created a legally cognizable injury and gave citizens the right to redress that injury in court.

The Court was correct to stress this point, and as we shall see, the emphasis on congressional instructions carries with it a number of important implications. Justice Scalia's dissenting opinion is also correct insofar as it contends that the Court suggests that Congress may create an interest in information and allow people to vindicate that interest in court. But Justice Scalia is wrong to suggest that this outcome would violate the Constitution.

\section{A. Injuries, in Fact and in Law}

Begin with the idea of "injury in fact." The Court held that there was such an injury in Akins because the plaintiffs were denied information to which they had a legal right. ${ }^{133}$ Because the statute created a right to information of which they were deprived, the plaintiffs suffered an injury that was sufficient for Article III purposes. Was the Court correct in reaching this conclusion?

\section{Preliminaries: Of Fact and Law}

To answer this question, it is necessary to step back a bit. There now appears to be a consensus that the "injury in fact" idea has extremely serious problems. ${ }^{134}$ The first problem is that the idea is not a product of the text or history of the Constitution; it is a recent innovation by the Court itself. ${ }^{135}$ To be sure, the text of the Constitution does require a "case" or "controversy," and this provision does limit the kinds of claims that can be heard in court. ${ }^{136}$ Without some kind of cause of action-with a purely ideological

${ }^{133}$ See id. at 1784 ("The injury of which respondents complain-their failure to obtain relevant information - is injury of a kind the FECA seeks to address ....").

${ }^{134}$ See Lee A. Albert, Standing to Challenge Administrative Action: An Inadequate Surrogate for Claim for Relief, 83 YALE L.J. 425, 492 (1974) (suggesting that the standing question is not injury in fact, but cause of action); David P. Currie, Misunderstanding Standing, 1981 SUP. CT. REV. 41, 42 (same); William A. Fletcher, The Structure of Standing, 98 YALE L.J. 221, 229 (1988) (arguing that standing should not require injury in fact); Richard B. Stewart, The Reformation of American Administrative Law, 88 HARV. L. REV. 1669, 1737-39 (1975) (discussing the problems of injury in fact when the injury is to an ideological interest). Many authorities to this effect are collected in Fletcher, supra, at 223 n.18.

${ }^{135}$ Specifically, the test is an outgrowth of Association of Data Processing Serv. Orgs. $v$. Camp, 397 U.S. 150 (1970). The origins of the test lay in the 1958 treatise by Professor Kenneth Culp Davis. See 3 KENNETH CULP DAVIS, ADMINISTRATIVE LAW TREATISE § 22.02, at 211-13 (1958) (arguing that as a matter of elementary justice, "one who is in fact hurt by illegal action should have a remedy").

${ }^{136}$ See U.S. CONST. art. III. 
objection or complaint-there is no "case" or "controversy" within the meaning of Article III. It follows that courts cannot hear objections unaccompanied by some kind of legal right to initiate suit. But both before and after ratification, legislatures-including the very first Congress-gave citizens and taxpayers causes of action in certain circumstances, and these causes of action were not thought to violate Article III. ${ }^{137}$ The injury in fact test has its roots not in the founding period, but in New Deal era cases, and did not take Article III form until about $1970 .^{138}$ As a matter of text and history, the best reading of the Constitution is that no one can sue without some kind of cause of action. An injury in fact, however, is neither a necessary nor a sufficient condition for standing.

There are problems with the injury in fact test even if we put text and history to one side. The test was originally designed to simplify the standing inquiry by separating the issue of standing and the merits, ${ }^{139}$ but it has actually produced extremely complex and unwieldy threshold issues of fact, ill suited to judicial resolution-involving, for example, the question of how, exactly, fuel economy standards alter the mix of available automobiles for consumers. ${ }^{140}$ But a more important problem with the injury in fact idea is conceptual: the test is not even coherent. ${ }^{141}$ The basic difficulty is that many people suffer injuries "in fact" every day, but these injuries do not be-

137 See Raoul Berger, Standing to Sue in Public Actions: Is It a Constitutional Requirement?, 78 YALE L.J. 816, 817 (1969) (arguing that the English precursor of standing "did not in fact demand injury to a personal interest as a prerequisite"); Louis L. Jaffe, Standing to Secure Judicial Review: Public Actions, 74 HARV. L. REV. 1265, 1265 (1961) (reviewing the common law development of public actions to protect public interests and contrasting the limitations that standing places on these actions); Cass R. Sunstein, What's Standing After Lujan? Of Citizen Suits, "Injuries," and Article III, 91 MiCH. L. REV. 163, 176 (1992) (discussing evidence that "Article III did not impose constraints on Congress' power to grant standing to strangers"); Steven L. Winter, The Metaphor of Standing and the Problem of SelfGovernance, 40 STAN. L. REV. 1371, 1395 (1988) (suggesting that in early Supreme Court jurisprudence, the Court did not recognize a cause of action in terms of "standing," but rather in formalistic terms).

A competing view of the history is provided in Bradley S. Clanton, Standing and the English Prerogative Writs, 63 BROOK. L. REV. 1001 (1997). I cannot discuss Professor Clanton's valuable treatment here; note, however, that even if he is correct on eighteenthcentury law, the early American practice argues against any "injury in fact" requirement.

${ }^{138}$ See Sunstein, supra note 137, at 179-81 (providing a historical overview of standing during the New Deal).

${ }^{139}$ See Camp, 397 U.S. at 153 (distinguishing between the legal interest test, which goes to the merits, and the question of standing).

${ }^{140}$ See Center for Auto Safety v. Thomas, 806 F.2d 1071, 1075 (D.C. Cir. 1986) (holding that as a membership organization, the petitioners had standing because they sought to protect the interests of their members in the choice of the most fuel efficient vehicles).

141 See Fletcher, supra note 134, at 221 (stating that "[t] the federal courts has long been criticized as incoherent"). 
come legally cognizable, and are not even visible to the legal system, unless and until some source of law creates a relevant legal interest and a right to bring suit. The legal system does not "see" an injury unless some law has made it qualify as such. If this point seems obscure, it is only because of widespread agreement, within the legal culture, about which injuries are "injuries in fact" and which are not. But the agreement comes from understandings of law, not understandings of fact.

Thus, for example, if a citizen sought information from the government in 1956 and even claimed that his request involved "the right to information," his complaint would have seemed purely ideological, and he would not have had standing. It is only after the passage of FOIA that there is a legal claim and hence an injury (in fact?) that is the basis for a federal cause of action. If a woman sued for sexual harassment in 1958, her injury would seem purely ideological and would not support a federal action; things are altogether different in 1999. Can it possibly be suggested that the "facts" have changed? If someone was turned down for a job in 1954 because of his skin color and complained about the rejection in court, there would have been no possible basis for a lawsuit. Things changed in $1964 .{ }^{142}$ The reason is not that the facts are different; it is the law that has changed. The line between injuries in fact and "other" injuries is usually clear, and it cannot possibly be one involving just "facts"; it necessarily involves the requirements of law.

To say this is to say that under Article III, an injury in fact is not an intelligible basis for standing. Something involving a violation of the law is required. But-it might be asked-is not an injury in fact a necessary or minimal condition for standing, as the Court has suggested in many cases since $1980 ?^{143}$ The most important problem with this question is that it is hard to know what the question means. For the question to be a sensible one, we would have to be able to think that there is a way, entirely independent of law, of figuring out whether a litigant has been "injured" at all. Some cases may seem quite easy on this count. If I sue to prevent the government from taking my land, surely I have been injured "in fact." If I am an Illinois citizen and sue to prevent racial discrimination in North Carolina, a state that I never visit, surely my interest is purely ideological. These

${ }^{142}$ See 42 U.S.C. $\$ 2000$ e (1994) (detailing the provisions of the Equal Employment Opportunities Act).

${ }^{143}$ See, e.g., Lujan v. Defenders of Wildlife, 504 U.S. 555, 560 (1992) (requiring injury in fact as an element of standing); Sierra Club v. Morton, 405 U.S. 727, 740-41 n.16 (1972) (citing 1 ALEXIS DE TOCQUEVILLE, DEMOCRACY IN AMERICA 280 (Phillips Bradley ed., A.A. Knopf 1945) (1835)), for the assertion that "judicial review is effective largely because it is not available simply at the behest of a partisan faction, but is exercised only to remedy a particular, concrete injury"). 
cases seem to suggest that common sense, or ordinary perceptions, can tell us whether someone has really, or "in fact," been injured, quite apart from the law.

But this conclusion is much too quick. "Injuries" are not some kind of Platonic form, so that we can distinguish, without the aid of some understanding of law, between those that exist "in fact" and those that do not exist "in fact." What is perceived, socially or legally, as an "actual" injury is a product of social or legal categories giving names and recognition to some things that people, prominently people within the legal culture, consider to be (actual, cognizable) harms. Takings cases, and cases involving Illinois citizens suing about discrimination in North Carolina, seem easy, and they are, but this is only because the relevant legal understandings are so deeply internalized that they appear to be mere "common sense." That these cases are easy is a tribute to the agreed-upon nature of the relevant legal understandings; it is not a product of any simple or law-free understanding of the "facts." The only way to distinguish between cognizable and noncognizable injuries is to see what the law says, or is; there is no prepolitical or prelegal way of making that distinction. ${ }^{144}$

\section{The Akins Reformulation}

Thus far these objections seem to run counter to the whole thrust of modern standing doctrine. But the Court has shown unambiguous signs of acknowledging this point. ${ }^{145}$ The Akins Court was alert to these problems and indeed seems to have taken the injury in fact test in a new, and far more productive, direction.

Note first that the Court seems to meld the injury in fact inquiry with the inquiry into what the law is: "The 'injury in fact' that respondents have suffered consists of their inability to obtain information ... that, on respon-

144 A hard case for this proposition would be created if Congress said that anyone may sue for any acts of unlawful racial discrimination anywhere. Would this not be a case of someone being given standing, or a legal right, when she had no injury in fact? I think that this question, meant to be rhetorical, is too simple; relevant discussion can be found infra, at Part IV.E.

145 See, for example, Lujan, where the Court, in introducing the standing requirements, said that "the plaintiff must have suffered an 'injury in fact'-an invasion of a legally protected interest." 504 U.S. at 560 (emphasis added). See also International Primate Protection League v. Administrators of Tulane Educ. Fund, 500 U.S. 72 (1991), where the Court said that "standing is gauged by the specific common-law, statutory or constitutional claims that a party presents," and noted that standing "should be seen as a question of substantive law, answerable by reference to the statutory and constitutional provision whose protection is invoked." Id. at 77 (quoting Fletcher, supra note 134, at 229). 
dents' view of the law, the statute requires that AIPAC make public."146 This formulation unambiguously mixes the injury in fact inquiry with an inquiry into the content of the law. The Court does not refer merely to an inability to obtain information; it refers to an inability to obtain information that must, under the relevant law, be made public. Here is a suggestion that without FECA, it is not clear that there would be a legally cognizable "injury."

The point emerges even more straightforwardly from the Akins Court's treatment of United States $v$. Richardson, ${ }^{147}$ where it is made clear that the injury in fact question would be assessed by reference to positive law, whether statutory or constitutional. If the citizens in Richardson had claimed standing qua citizens, the legal issue "would have rested in significant part upon the Court's view of the Accounts Clause."148 Quoting Richardson, the Court said that there would thus be an issue "whether "the Framers...ever imagined that general directives [of the Constitution] ... would be subject to enforcement by an individual citizen." 149 In other words, Akins was different from Richardson: in Akins, Congress had expressly said that the widely diffused interest could be enforced by individual litigants, whereas in Richardson, it was not at all clear that the relevant source of law (the Constitution) said that the relevant, widely diffused injury could be enforced by individual litigants. Whether there was injury "in fact" depended on what had been provided "in law."

This is a striking way to understand the inquiry into "injury in fact." It suggests unambiguously that whether a perceived harm is legally cognizable depends not on facts, but on law. If a denial of citizen standing was appropriate in Richardson, it was not because there was no injury "in fact," but because there was no injury in law-that is, because no source of law created a right to bring suit. This suggestion is compatible with several promising pronouncements in previous cases. ${ }^{150}$ In Lujan itself, the Court said that part of the injury in fact test involved whether a "legally cognizable" interest was involved. ${ }^{151}$

I conclude that the principal question after Akins, for purposes of "injury in fact," is whether Congress or any other source of law gives the liti-

146 Federal Election Comm'n v. Akins, 118 S. Ct. 1777, 1784 (1998).

147418 U.S. 166 (1974).

148 Akins, 118 S. Ct. at 1785.

149 Id. (quoting Richardson, 418 U.S. at 178 n.11) (alteration in original).

150 See, e.g., Air Courier Conference v. American Postal Workers Union, 498 U.S. 517, 523 (1991) (stating that in order to sue under the APA, one must establish that she has suffered a legal wrong as the result of an agency's action).

151 See Lujan v. Defenders of Wildlife, 504 U.S. 555, 578 (1992) (affirming the principle that only "legally cognizable injuries" satisfy the requirements of Article III). 
gant a right to bring suit. ${ }^{152}$ Previous cases suggest that there are limits on Congress's power to grant standing to people who have sustained no "injury in fact," 153 and these cases have not been overruled by Akins. But at least where the plaintiff seeks information, and where Congress has created a legal interest and a right to bring suit, the Constitution does not stand as an obstacle. This is, to say the least, a major development in the law of informational standing. It is also a promising development, because it puts the standing question in the hands of Congress, where it belongs. And even if this statement is controversial in its broadest form-applying outside the context of information ${ }^{154}$-it should not be controversial in a case in which Congress expressly gives people a right to receive information and allows them to bring suit to vindicate that right in court.

\section{B. Generalized Grievances}

Perhaps the most important aspect of the Akins decision is the Court's novel understanding of the old idea that "generalized grievances" are not subject to judicial protection. Before Akins, it was fair to say that the ban on generalized grievances was moving from a prudential one to one rooted in Article III. ${ }^{155}$ Lujan seemed to suggest that to have standing, citizens would have to show that their injuries were "particular" in the sense that they were not widely shared. ${ }^{156}$ This was the view defended in an influential law re-

${ }^{152}$ See United States House of Representatives v. United States Dep't of Commerce, 11 F. Supp. 2d 76, 85 (D.D.C. 1998); Judicial Watch, Inc. v. Federal Election Comm'n, 10 F. Supp. 2d 39, 41 (D.D.C. 1998).

${ }_{153}$ See Lujan, 504 U.S. at 576-77 (rejecting the proposition that courts act as pseudolegislatures by accepting cases without a person suffering "distinctive concrete harm"); Sierra Club v. Morton, 405 U.S. 727, 740 (1972) ("The requirement that a party seeking review must allege facts showing that he is himself adversely affected does not insulate executive action from judicial review, nor does it prevent any public interests from being protected through the judicial process.").

${ }^{154}$ I do not suggest that Akins overrules Lujan insofar as the latter case requires an injury in fact. All that is clear is that after Akins, a deprivation of information consists of an injury in fact if Congress has said so. The tension between Akins and Lujan stems from the Akins Court's recognition that whether there is an injury depends on what Congress has said, and its clear indication that Congress has the power to create new interests and new injuries. It remains to be seen whether and how Akins alters Lujan's apparent belief that "injury" is a kind of Platonic form, existing above and apart from the law. For a quite extreme example of the Platonic form view of standing law, see Animal Legal Defense Fund, Inc. v. Glickman, 154 F.3d 426, 445-50 (D.C. Cir. 1998) (Sentelle, J., dissenting).

${ }^{155}$ See Lujan, 504 U.S. at 573-74 (stating that making a generalized grievance claim against the government "does not state an Article III case or controversy").

${ }^{156} \mathrm{See}$ id. at $574-75$ (quoting with approval Doremus v. Board of Educ., 342 U.S. 429, 433-34 (1952), which stated that "to invoke the judicial power ... it is not sufficient that [the citizen] has merely a general interest common to all members of the public"). 
view article by then-Judge Scalia, which Lujan appeared to follow. ${ }^{157}$ The article urged that the distinctive role of the courts is to protect individual rights, and that when numerous people are being injured, their remedy is political rather than judicial. This claim was bottomed, in turn, on the idea that the distinctive role of the courts is to vindicate rights held by individuals, rather than majorities or large groups. ${ }^{158}$ There were many suggestions, in the lower courts as well as the Supreme Court, that prudential or constitutional considerations counseled against standing for those whose injuries were not individuated. ${ }^{159}$ These suggestions were especially important in cases involving information, since the interest in receiving information is often widely shared-sometimes, in fact, shared by millions of citizens, as in the typical deprivation of information suit under FECA.

The Akins Court makes what reasonably could be considered either an important clarification or a dramatic shift. After Akins, the fact that an injury is generalized is not a barrier to standing under Article III. Congress is entirely authorized to grant standing to individuals who share an injury with many other people, even with all citizens. Akins reads the references to generalized grievances in connection with the requirement that injuries be concrete rather than abstract. Concreteness, the Court says, is indeed a constitutional requirement. Injuries must not be speculative. But an injury that is both concrete and generalized is constitutionally cognizable. ${ }^{160}$

Frequently, this is the case with a denial of information. The person who has been denied information suffers a concrete harm, even though she may be part of an extremely large class of people. As we have seen, this is the point where Justice Scalia departed, with some alarm, from the Akins majority, on the theory that any injury must be both concrete and "particularized" in the sense that it must be distinct to the complaining individual. ${ }^{161}$ Frequently, a plaintiff seeking information would run afoul of this require-

157 See Scalia, supra note 131, at 881-82 (1983) ("I suggest that courts need to accord greater weight than they have in recent times to the traditional requirement that the plaintiff's alleged injury be a particularized one, which sets him apart from the citizenry at large.").

${ }_{158}$ See id. at 894-97 (arguing that "the law of standing roughly restricts courts to their traditional undemocratic role of protecting individuals and minorities against impositions of the majority").

${ }^{159}$ See, e.g., United States v. Richardson, 418 U.S. 166, 179-80 (1974) (stating that a citizen who is not satisfied with a congressional ruling can resort to the electoral process as a remedy, and that there is a "basic principle that to invoke judicial power the claimant must have a 'personal stake in the outcome,' or a 'particular, concrete injury,' or 'a direct injury"' (citations omitted)).

${ }^{160}$ See Federal Election Comm'n v. Akins, 118 S. Ct. 1777, 1786 (1998) ("[W] harm is concrete, though widely shared, the Court has found "injury in fact."').

${ }^{161}$ See id. at 1791 (Scalia, J., dissenting) (stressing the importance of a "particularized" injury). 
ment, for often those deprived of information are not injured in a way that is (in Justice Scalia's particular sense) particular.

What, then, remains of the supposed ban on generalized grievances? Very little-but not nothing. The Court says that the fact that an injury is widely shared, and hence the political forum is available, will "counsel[] against ... interpreting a statute as conferring standing." "Hence, the notion is retained as a prudential one, and as we will see, it may turn out to be quite important as such, in information cases and in others. ${ }^{163}$

Now, it would be possible to suggest that Akins eliminates the "generalized grievance" requirement entirely and focuses solely on injury in fact. The Court's use of the mass tort case-in which numerous people are affected, but each has standing-might be taken as indicative of a move in this direction. In the mass tort case, however, many people are affected, but each in a particular and concrete way. A more serious question is whether the same is true when thousands or millions of people are deprived of information. It is not easy to answer that question in the abstract. Perhaps a deprivation of information (involving, for example, television ratings) affects each individual particularly and concretely. But the Court should probably be taken at its word with its suggestion that a widely generalized injury is not cognizable if Congress has not expressly said that it is.

An especially narrow reading of Akins would fasten on the following sentence: "We conclude that similarly, the informational injury at issue here, directly related to voting, the most basic of political rights, is sufficiently concrete and specific such that the fact that it is widely shared does not deprive Congress of constitutional power to authorize its vindication in the federal courts." 164 A future court could possibly read Akins as crucially about information directly related to voting. Such a court could plausibly say that the Akins Court allowed standing for citizens asserting a generalized grievance only because, and to the extent that, the injury involved "the most basic of political rights."

The first question here is obvious: Was the Court correct to say that Article III poses no barrier to those who have grievances that are both concrete and widely shared? As a matter of text and history, the Court's conclusion is unimpeachable; there is no constitutional barrier to judicial recognition of legally authorized claims asserted by citizens whose interests are widely shared. ${ }^{165}$ Generalized grievances were recognized in both England

162 Id. at 1786.

163 See infra notes 209-41 and accompanying text.

164 Akins, 118 S. Ct. at 1786.

165 See Berger, supra note 137, at 816,840 ("[T] injury to a personal interest as a prerequisite to attacks on allegedly unconstitutional action is 
and America, where, as we have seen, citizen and taxpayer standing was permitted. ${ }^{166}$ Even if it were possible to generate from text and history a constitutional requirement of an "injury," such a requirement would not stand as an obstacle to suits by people who suffer along with many others. Such people have injuries, too; they are not mere bystanders, and they are not complaining about violations of law as such. Thus the Court's conclusion that widely generalized injuries are cognizable is right even if we agree that some "injury in fact" test is constitutional in character.

In both judicial and nonjudicial writing, Justice Scalia has defended the ban on generalized grievances not by reference to text and history, but instead by invoking considerations of policy and structure. ${ }^{167}$ In his view, the ban stems from an understanding of the distinctive role of the judiciary in a democratic society. Courts properly protect individuals, or members of small groups, against governmental illegality. But when injuries are widely shared, the victims can and should use the political process, not the courts, for they have (by hypothesis) sufficient political voice to resort to their democratic remedies. In the context of information, the argument would be that if government is refusing to regulate (for example) AIPAC as a political committee, and thus refusing to require it to disclose relevant information, then a large number of people are harmed. They should have enough political influence to be able to pressure the FEC and Congress to respond. That is the appropriate arena for their claims, not the judiciary.

As a matter of political science, this is not an entirely implausible set of generalizations; a large group certainly has more access to political remedies than a small one, other things being equal. But the generalization is crude. Whether it is right depends on a number of variables, including the information and the organizational capacity of the relevant group members, who may face serious collective action problems. ${ }^{168}$ Return here to a basic reason for statutes requiring information disclosure and indeed for grants of standing in public law cases: when a large group of people is denied infor-

historically unfounded."); Louis L. Jaffe, Standing to Secure Judicial Review: Public Actions, 74 HARV. L. REV. 1265, 1307-14 (1961) (explaining that the Constitution does not bar a shared interest suit). See generally Winter, supra note 137, at 1418-25 (explaining the ontological development of the term "standing").

${ }_{166}$ See Sunstein, supra note 137, at 171 ("In both England and America, actions by strangers, or by citizens in general, were fully permissible and indeed familiar."); Winter, supra note 137, at 1441-57 (describing constitutional standing).

${ }^{167}$ See Akins, 118 S. Ct. at 1791-92 (Scalia, J., dissenting) (arguing that such suits undermine the powers of the Chief Executive); Scalia, supra note 131, 894-97 (arguing that courts should not be political instruments).

${ }_{168}$ See generally RUSSELL HARDIN, COLLECTIVE ACTION 6-9 (1982) (analyzing collective action problems); MANCUR OLSON, THE LOGIC OF COLLECTIVE ACTION 1-2 (2d ed. 1971) (explaining that without a coercive force, groups may not take steps to advance their common or group interests). 
mation, many or most of them may not know that they have been harmed; and even if they know, any particular member-say, member A-may not consider it worthwhile to participate in the relevant political activity. This is especially so in light of the fact that nothing is likely to happen unless other members act, in which case little will be added by the participation of member $A$. With respect to information in particular, the free rider problem is likely to make political remedies insufficient, even or especially when large numbers of people have been deprived of information to which they have a legal right.

Justice Scalia's argument is basically one from democracy: when many people are injured, they should use the democratic process, not the courts. But as a claim from democracy, the argument is weak. The most basic difficulty is that Congress has, by hypothesis, concluded that the agency (or private defendant) is not entirely reliable on its own and that relevant people should have access to the courts in order to ensure that the (democratically enacted) law is enforced. If Congress has made that judgment, then there should be no (democratic) problem with allowing that kind of enforcement of the statutory directive. If Congress has given anyone the right to ensure disclosure of campaign-related information, it is because Congress was concerned that the FEC would not adequately enforce the law, and because Congress believed that a right to challenge FEC decisions in court would increase the likelihood of good outcomes. Perhaps that judgment was unwise; perhaps citizen suits cause more trouble than they are worth. But that would be a policy problem, not a constitutional one. ${ }^{169}$

There is also nothing in Article II that argues against allowing standing for people who suffer a widely shared injury. To be sure, it is for the Executive, not the courts, to "take Care" that the laws are faithfully executed. In these cases, however, the plaintiffs' allegation is that the Executive has failed in that task. In order to prevail, the plaintiffs must overcome a substantial burden by showing (to simplify a complex story) that the agency has violated an unambiguous statute ${ }^{170}$ or has behaved in an arbitrary or capricious manner. ${ }^{171}$ It does no violence to Article II for a court to hear a plain-

169 There is a difference here between standing in constitutional cases and standing in administrative law cases. Perhaps courts should be cautious in allowing citizens to invoke the Constitution to challenge the outcomes of the democratic process. Even if this is so, however, there is far less reason for courts to be cautious in allowing people to invoke statutes to challenge the outcomes of the administrative process.

${ }^{170}$ See Chevron U.S.A. Inc. v. Natural Resources Defense Council, Inc., 467 U.S. 837, 842-43 (1984) ("If the intent of Congress is clear, ... the court, as well as the agency, must give effect to the unambiguously expressed intent of Congress.").

${ }^{171}$ See 5 U.S.C. $\S 706(2)(A)$ (1994) (mandating that the reviewing court "hold unlawful and set aside agency action ... found to be ... arbitrary [or] capricious"). 
tiff's complaint to this effect and to rule against the Executive if it is shown that the agency has, in fact, violated the law.

\section{Redressability}

With respect to redressability, the Court proceeded with an analogy that operated as a kind of reductio ad absurdum. With some incredulity, the Court indicated that if this injury was not redressable, then the same would be true of countless complaints in countless administrative law cases, where agencies might also end up rejecting the plaintiffs' complaints after remand. The point is correct; the logic of the government's redressability argument might well have this extraordinary consequence.

It also seems clear that Akins marks a noteworthy clarification of preexisting law. The prior cases ${ }^{172}$ seemed to suggest that standing should not be permitted if there is any nontrivial reason to think that a discretionary decision, by the agency or a private party, might prevent the plaintiff from obtaining the requested relief. In Akins, this idea is rejected; standing exists even in the face of a substantial possibility that the agency would exercise its discretion to the plaintiff's detriment. We might even say that after $A k$ ins, the redressability requirement is unlikely to matter in the administrative law context, at least where the exercise of agency discretion on remand is what makes the remedy "speculative."173

But the Court's explanation nonetheless leaves a good deal to be desired. Under the Court's existing redressability cases, it has yet to be explained why, in principle, there is no serious problem in conventional administrative law cases. We know that there is no such problem; we do not know why.

To be more concrete: the Court made clear that Article III requires the plaintiff to show that a decree in his favor will remedy his asserted injury. It must not be "speculative" whether the decree would do so. In Linda R.S. v.

${ }^{172}$ See Allen v. Wright, 468 U.S. 737 (1984), Eastern Kentucky Welfare Rights Organization v. Simon, 426 U.S. 26 (1976), and Linda R.S. v. Richard D., 410 U.S. 614 (1973), discussed infra, at notes 174-77 and accompanying text.

${ }^{173}$ See Animal Legal Defense Fund, Inc. v. Glickman, 154 F.3d 426, 445-49 (D.C. Cir. 1998) (Sentelle, J., dissenting). Akins does not disturb previous law insofar as it is focused on the exercise of discretion by a private party. See Allen v. Wright, 468 U.S. 737 (1984) (exercise of discretion by private schools); Eastern Ky. Welfare Rights Org. v. Simon, 426 U.S. 26 (1976) (exercise of discretion by nonprofit hospitals); Linda R.S. v. Richard D., 410 U.S. 614 (1973) (exercise of discretion by parent). But it is not clear, on the Court's view, why this should make a substantial difference. I suggest below that the different results really turn on the statutory interpretation-that is, on an understanding of Congress's instructions under the relevant statute. 
Richard D., ${ }^{174}$ for example, the mother of a child born out of wedlock challenged the local prosecutor's failure to bring proceedings against her child's father for failure to pay child support. The Court denied standing on the ground that even if the prosecutor initiated proceedings, the father might not pay. ${ }^{175}$ So, too, in Simon v. Eastern Kentucky Welfare Rights Organization ("EKWRO"), where indigent individuals, denied emergency services in local hospitals, brought suit against the Internal Revenue Service challenging a new policy that allowed hospitals to claim a charitable deduction after providing fewer emergency services to the indigent. ${ }^{176}$ The Court denied standing on the ground that it was possible that even if the charitable deduction had been unchanged, services might have been denied. ${ }^{177}$ Thus, a decree in the plaintiffs' favor would not have prevented or redressed their injuries. In both cases, the Court seemed concerned that a grant of standing would have allowed a kind of advisory opinion.

The problem here is that many conventional administrative law cases seem to have precisely the same difficulty; there is no assurance that a plaintiff will ultimately receive what he wants even if he succeeds on the issue at hand. Thus, for example, if a plaintiff complains that the agency failed to give an adequate explanation for a rule, there is no assurance that on remand, the agency will not come up with exactly the same rule after justifying itself adequately. The plaintiff's victory may not result in an outcome in his favor. The central question, unanswered in Akins, is this: Why, then, do the redressability requirements not create problems in ordinary administrative law cases?

The beginning of an answer may seem to lay in a controversial explanation in the Lujan opinion, consisting chiefly of a footnote ${ }^{178}$ in which the Court suggested that the redressability requirements would be relaxed in

174410 U.S. 614 (1973).

175 See id. at 619 (holding that the mother lacked standing since she had not shown that the prosecution of the father would vindicate her interest).

176426 U.S. 26 (1976).

177 See id. at $42-43$ ("It is purely speculative whether the denials of service specified in the complaint fairly can be traced to petitioner's 'encouragement' or instead result from decisions made by the hospitals without regard to the tax implications."). See also Allen, 468 U.S. 737, where the Court denied standing to parents of black children attending public schools undergoing desegregation. The plaintiffs attempted to challenge the grant of tax deductions to segregated public schools. The Court held that the denial of the tax deduction would not necessarily affect the plaintiffs. See id. at 758 ("I]) is entirely speculative... whether withdrawal of a tax exemption from any particular school would lead the school to change its policies."). After Akins, both EKWRO and Allen might be seen as cases in which Congress did not create standing; as a matter of construction of the Internal Revenue Code, third parties usually lack standing to litigate the tax liability of others.

${ }^{178}$ Lujan v. Defenders of Wildlife, 504 U.S. 555, 572 n.7 (1992). 
some cases involving a "procedural injury," such as where a plaintiff complains of the failure to prepare an EIS. Standing is available if plaintiffs "are seeking to enforce a procedural requirement the disregard of which could impair a separate concrete interest of theirs." mere preparation of an EIS need not have favorable consequences for any plaintiff; the agency may prepare the statement and go ahead with its plans undaunted. But if a concrete recreational or health interest "lies behind" the complaint, then this fact is not fatal to standing by a NEPA plaintiff. Thus the Court said that a "person who has been accorded a procedural right to protect his concrete interests can assert that right without meeting all the normal standards for redressability and immediacy." "This was essentially the logic that the Court followed in Akins, without citing the Lujan suggestion. And we can agree that the redressability requirements should not be taken to forbid people from complaining about procedural violations that are connected with injuries to their legally cognizable interests. But the question remains: Why is this so?

The best response has to do with the nature of procedural rights and their distinctive relation to the question of redressability. When Congress creates a procedural right, it does so not because the right will necessarily lead to particular results, but instead because procedural rights create desirable structures, incentives, and increased or decreased probabilities-and also because they increase the legitimacy of any government interference with substantive rights. In Congress's apparent view, those structures, incentives, and probabilities tend to produce outcomes that are better or more fair. This is the underlying logic of the brief analysis in Lujan; NEPA is designed not to require particular results, but to structure processes in a way that will increase the likelihood of good or fair decisions. Once properly characterized-as involving a right to certain procedures rather than certain outcomes-the statutory injury would be redressed. When a court holds that an agency has not complied with NEPA and requires the preparation of an EIS, the court has redressed the plaintiff's NEPA-related injury. That injury does not consist of an environmental injury alone, or even at all; the injury consists of the failure to provide the beneficiaries of NEPA with the procedural protections (and agency incentives) created by that statute. The key point here is that we cannot know whether the redressability requirements are met without properly characterizing the relevant injury, and the only basis for a proper characterization is the statute. NEPA gives rise to a 
new and distinctive set of injuries, and those injuries are precisely redressed through a mandate that agencies prepare (legally required) EISs.

A similar situation arises with the campaign finance law in Akins. Perhaps the agency would decide, on remand, to exercise its discretion not to challenge AIPAC, but at least it would be doing so as an exercise of prosecutorial discretion and not on the basis of what would be (by hypothesis) an illegitimate interpretation of FECA. A central point of the APA arrangement for judicial review of administrative action is to ensure that agencies proceed both publicly and on the basis of legitimate reasons. The plaintiffs in Akins alleged that the FEC misinterpreted the relevant law, and the relevant injury-government inaction threatening to their statutory rights in their capacity as citizens, based on that misinterpretation-would be adequately redressed by a decision in their favor. The general conclusion is that characterization of the injury comes from the governing statute. This conclusion cuts across standing doctrine and indeed applies in information cases quite broadly.

The point incidentally explains why Justice Scalia was able to attract only a plurality on the redressability question in Lujan itself. There, the plurality concluded that the plaintiffs, challenging federal funding of an international project that threatened certain endangered species, should be denied standing because they could not show that the denial of federal funding would save any endangered species. ${ }^{181}$ The plurality noted that even if the plaintiffs prevailed, and the Secretary of the Interior determined that the funding was unlawful, the funding agencies might not change their behavior. The Court also noted that American agencies provide only a part of the funding for the relevant foreign projects and hence a denial of federal funds might not save the relevant species. ${ }^{182}$ If the plurality's reasoning is right, then the redressability reasoning of the Akins Court is probably wrong. But the plurality's reasoning is not right. Insofar as the Endangered Species Act forbids the use of federal funds to jeopardize the continued existence of endangered species, its purpose is not necessarily to preserve endangered species (an outcome that depends not only on federal funding or even federal action), but to ensure that the American government does not take actions that contribute to their elimination. The injury that the plaintiffs sought to address was the increased probability of extinction that would be created by the unlawful use of federal funds.

181 See id. at 571 (stating that "[r]espondents have produced nothing to indicate that the projects they have named will either be suspended, or do less harm to listed species, if that fraction is eliminated").

182 See id. (noting that the agency provided less than $10 \%$ of the funding). 
If the injury is understood in these terms, the redressability requirement is met by showing that if the plaintiff prevailed, then the funds would not be used in the unlawful manner. The six justices who joined the majority opinion in Akins straightforwardly have rejected the four-person opinion in Lujan. These claims about redressability are closely related to the claims about injury in fact offered above. Both injury in fact and redressability are crude ways of getting at the central question: What kind of injury is created by the relevant source of law?

There is an important corollary. When a plaintiff seeking to attack an institution objects to an unlawful expenditure of federal funds-involving, for example, schools that discriminate on the basis of race or sex-standing is available even though a withdrawal of funds may not prevent the discrimination. The injury consists of the increased probability or dimensions of discrimination by virtue of government funding, or of the use of federal funds to subsidize discrimination; that injury would be redressed by the decree the plaintiff seeks. ${ }^{183}$

These points help sort out the whole area of procedural injuries. When a concrete interest lies behind a procedural violation, a plaintiff has standing to bring suit, even if the agency, after complying with applicable procedures, might not give the plaintiff the relief he seeks or might proceed on a course that the plaintiff dislikes. For purposes of informational standing, the course for the future is therefore clear. Even if an agency might not proceed against a third party to require disclosure of information, a plaintiff with congressional authorization has standing to object to the procedures that the agency followed in choosing that course. This is not because the redressability requirements are "relaxed" in procedural cases (as the Lujan Court would have it), but because the injury, properly characterized in light of the underlying (procedural) law, would be redressed by a decree in the plaintiff's favor (consider NEPA and funding cases above as examples).

These answers also help to recast the whole idea of redressability, certainly, but not only, in cases involving access to information. Whether an injury is redressable depends on how it is characterized, and how it is characterized depends on the nature of the relevant law. In procedural cases, a plaintiff with a concrete interest faces no redressability problem if the governing law also creates a legally cognizable interest in the relevant structures and incentives-so, too, with other standing cases. Consider, as Ex-

${ }^{183}$ The point suggests that EKWRO and Allen were incorrectly decided if they are taken as pure redressability cases. But if they are taken as cases about congressional instructions, then they were probably correct, because Congress is generally not understood to allow one taxpayer to litigate the tax liability of another. 
hibit A, Northeastern Contractors, ${ }^{184}$ in which white construction contractors challenged an affirmative action program, only to meet with the seemingly plausible objection that they could not show that they would have received the contracts without the affirmative action program. The Court responded that this showing was irrelevant; what was important was that the plaintiffs had suffered an injury to an interest protected by the Equal Protection Clause- that is, the opportunity to compete on an equal basis. ${ }^{185}$ That injury would have been addressed by a favorable decree. Although I cannot discuss the point in detail here, I believe that Northeastern Contractors, together with Akins, will eventually force a rethinking of the whole idea of redressability, requiring the Court to be more explicit about the kinds of "injuries" that it recognizes. ${ }^{186}$

The appropriate conclusion is that the Akins Court was correct to allow standing in the face of a redressability challenge, and also that it was correct to invoke the analogy of conventional administrative law cases. But the correctness of the result and of the analogy suggest deeper problems with redressability; the problems have to do with the need to characterize the injury properly. The proper characterization of the injury turns on the content of the relevant law, procedural or substantive.

\section{INJURIES AND INFORMATION IN THE FUTURE}

The discussion thus far suggests that the Akins Court was right on each of the three principal standing issues. ${ }^{177}$ But larger questions remain. For example, what are its implications for informational injury in the future? And how does it bear on standing questions not involving information injury at all?

184 Northeastern Fla. Chapter of Associated Gen. Contractors v. City of Jacksonville, 508 U.S. 656 (1993).

${ }^{185}$ See id. at 666 ("The 'injury in fact' in an equal protection case of this variety is the denial of equal treatment resulting from the imposition of the barrier [to compete for benefits], not the ultimate inability to obtain the benefit.").

${ }^{186}$ See Cass R. Sunstein, Standing Injuries, 1993 SuP. CT. REv. 37, for a general discussion on how injuries should be characterized for purposes of standing.

187 The Court was also right on the smaller issue, involving interpretation of the statute. Justice Scalia's disagreement was plainly motivated by his belief that the statute should be construed so as to avoid constitutional doubts. See Federal Election Comm'n v. Akins, $118 \mathrm{~S}$. Ct. 1777, 1789-90 (1998) (Scalia, J., dissenting) (urging the Court to adopt a "narrower reading of the phrase "party aggrieved" in order to avoid constitutional doubt). 


\section{A. Injury in Fact: Mostly Easy Cases}

After Akins, there are, with respect to information, many easy cases. If Congress granted standing to citizens in general to seek information and information has been withheld, citizens in general can bring suit. Certainly this is clear if the information bears directly on their behavior as voters. It seems equally clear if the information bears directly on the plaintiffs' activities in their individual or organizational capacities. Suppose, for example, that an individual or institution is interested in obtaining information relating to enforcement of the Animal Welfare Act, and that individual or organization has a demonstrable interest in the protection of animals from suffering. In such cases, standing is clearly available.

The situation is slightly less clear when an individual or institution seeking information invokes no interest expressly related to the political process and when that individual or institution cannot show that the information would relate to relevant activities on his or its part. The strongest argument for denying standing would be that the plaintiff has a purely ideological interest, or an interest in law enforcement for its own sake. Suppose, for example, that an ordinary, relatively young citizen is seeking information about compliance with the Age Discrimination Act. Suppose the citizen seeks this information simply because she is curious, or because she generally wants to make sure that the government is enforcing the law. It is possible to argue that Akins does not cover this case. As stated, the plaintiff has no particular interest as a citizen, and she cannot connect the denial of information to any tangible activity independent of the lawsuit. Thus, there is a plausible basis for denying standing even in light of the outcome in Akins.

The argument is plausible, but no more than that; a congressional grant of standing in a case of this kind would probably be constitutional after $A k$ ins. (If there is no such grant, then standing should probably be denied on prudential grounds.) ${ }^{188}$ The first point is analogical and involves FOIA. Under FOIA, anyone can bring suit to obtain any information that FOIA requires to be made public. ${ }^{189}$ The plaintiff need not show an interest in using the information for anything in particular; simple curiosity is enough. The denial of the information is the injury in fact. No court has held this provision unconstitutional. It is hard to distinguish the countless imaginable FOIA cases from the hypothesized case.

188 See the discussion of generalized interests within the zone, infra Part IV.C.

${ }^{189}$ See 5 U.S.C. $\$ 552$ (1994) (stating that agency rules, opinions, orders, records, and proceedings are public information). 
The second point involves Akins itself. The Akins Court could have issued a narrow ruling, saying that when citizens bring suit to obtain information directly involving the political process, there is no constitutional obstacle to a congressional grant of standing. As noted, there is some language in Akins emphasizing that the case itself involved voting, "the most basic of political rights," 190 and it would be possible to seize on this language to confine the opinion's reach. A narrow understanding of this kind, however, would not be consistent with the spirit of the decision, for the Court spoke far more generally about Congress's creation of a legal right to information and its grant of a right to bring suit to vindicate that interest. The remark about "the most basic of political rights" was in the nature of an exclamation point, and not in any sense central to the Court's reasoning.

In any case, it would not be sensible, for Article III purposes, to distinguish between citizens seeking information directly bearing on the political process and citizens seeking other kinds of information. If the question is whether the plaintiff has suffered injury in fact, then why would that line be appropriate? At best, such a line would invite strategic behavior and ingenious pleading; almost any information can plausibly be characterized as bearing on voting behavior. In the hypothesized case, for example, the plaintiff could contend, at least as plausibly as the citizens in Akins, that the relevant information would bear on her decision about how to vote, and in what kinds of political activity to engage. Putting the risk of strategic behavior to one side, nothing in Article III supports the view that Congress may create citizen standing in cases involving denial of information bearing on the right to vote, but may not do so when voting is not at stake. Article III requires a legal right-if Congress has created a legal right to information, that requirement is satisfied.

I conclude that after Akins, the injury in fact test is not a barrier to explicit congressional grants of standing to citizens seeking information to which they have a legal right. The real difficulties lie elsewhere; they have to do with redressability and with congressional instructions.

\section{B. Redressability: Information, Bounties, and the U.S. Treasury}

Suppose that the government or some private entity refused to disclose information, or suppose that the government failed to require disclosure of information by some third party, either public or private. Suppose, too, that the nondisclosure is unlawful. If a plaintiff sues to obtain the information, there is injury in fact, and the plaintiff meets the redressability requirements under Akins. Now instead suppose that the information has been disclosed 
after the filing of the complaint but before the judgment, and that the plaintiff seeks declaratory relief or the imposition of monetary penalties. The problem is far from hypothetical. Congress sometimes allows plaintiffs to impose financial burdens on both those who have failed to disclose information $^{191}$ and polluters (and others) who sometimes disclose information only after a lawsuit has been threatened or instituted. Is there a standing problem?

The easiest case for the plaintiff would involve monetary penalties that would go directly to the plaintiff. If a plaintiff stands to receive compensation for information unlawfully withheld, then the case is akin to many conventional cases in which a plaintiff seeks damages for illegality, and there is no standing question at all. If the plaintiff stands to receive a "penalty" not representing compensation but taking the form of a bounty, then the problem is a little harder, but there should be no problem here either. A potential award of a penalty or a bounty would make the case akin to several old prerogative writs, such as quo warranto, informer's actions, and qui tam actions. ${ }^{192}$ In Lujan, the Court suggested that a grant of a bounty to the citizen-plaintiffs would solve the constitutional difficulty, ${ }^{193}$ and there is support for this idea in the qui tam action, as suggested by early congressional practice and in several Supreme Court decisions. ${ }^{194}$

Suppose, however, that a plaintiff stands to gain no monetary relief at all; suppose that the plaintiff is entitled only to a declaratory judgment, with appropriate fines going to the U.S. Treasury. In a case of this kind, the Court recently held that there can be no informational standing. Steel Co. v. Citizens for a Better Environment involved a complaint, by a public interest organization, that Steel Company failed to disclose its toxic releases, in

191 See EPCRA, 42 U.S.C. $\$ 11045$ (c) (1994) (imposing civil and administrative penalties for failing to meet the reporting requirements of EPCRA).

192 See Sunstein, supra note 137, at 168-79 (describing the history of standing in the English and American systems).

${ }_{193}$ See Lujan v. Defenders of Wildlife, 504 U.S. 555, 572-73 (1992) (distinguishing Lujan from the simple case where standing exists because Congress has provided "a cash bounty for the victorious plaintiff').

194 See, e.g., Act of May 19, 1796, ch. 30, § 18, 1 Stat. 469, 474 (awarding private citizens bounties for informing the U.S. government of violations of the Act); Act of Mar. 22, 1794 , ch. $11, \S 4,1$ Stat. 347,349 (offering a bounty to persons who prosecute violations of the Act); Act of Feb. 20, 1792, ch. 7, \& 25, 1 Stat. 232, 235 (granting one half of the penalties collected to the person "informing and prosecuting" the violation); Act of March 3, 1791, ch. $15, \S 44,1$ Stat. 199, 209 (providing one half of all penalities collected for violation of the Act to the person who discovers the violation); United States ex rel. Marcus v. Hess, 317 U.S. $537,541 \mathrm{n} .4$ (1943) (supporting the Court's assertion that "[q]ui tam suits have been frequently permitted by legislative action"); Marvin v. Trout, 199 U.S. 212, 225 (1905) (asserting the standing of the plaintiffs to sue in qui tam actions). 
plain violation of EPCRA. ${ }^{195}$ All sides agreed that Steel Company had not done what it was legally obliged to do. Soon after Citizens for a Better Environment sent Steel Company a statutory notice of intent to sue, however, the company filed the overdue forms and disclosed the relevant information. The plaintiff claimed that the statute entitled it to various kinds of "appropriate" relief: a declaratory judgment that the company violated EPCRA, civil fines (of $\$ 25,000$ per day) that would be paid to the government, an award of costs, and an order requiring the company to provide them with copies of all compliance reports submitted to the EPA. ${ }^{196}$

Nonetheless, the Court denied standing. It did not reach the question of whether "being deprived of information that is supposed to be disclosed under EPCRA - or at least being deprived of it when one has a particular plan for its use-is a concrete injury in fact that satisfies Article III."197 (Akins answers that question affirmatively, though without the approval of Justice Scalia, who wrote the opinion in Steel Co.) Instead the Court simply concluded that the plaintiff could not meet the requirements for redressability. If the plaintiff won, how, exactly, would its injury be remedied? The Court explained that "[n]one of the specific items of relief sought, and none that we can envision as 'appropriate' under the general request, would serve to reimburse respondent for losses caused by the late reporting, or to eliminate any effects of that late reporting upon respondent."198 The result might have been different if the civil penalties could be "viewed as a sort of compensation or redress to" the plaintiff, but the fact that the penalties would go to the Treasury suggested that the plaintiff instead sought "not remediation of its own injury ... but vindication of the rule of law." 199

Steel Co. is important because it suggests a significant obstacle to informational standing: a plaintiff must show not only that there has been a deprivation of information, but also that the plaintiff stands to gain something from a decree in its favor. To be sure, it is reasonable to doubt the Court's decision, which was, on the constitutional issue, quite cavalier. ${ }^{200}$ As a matter of first principles, or as a matter of constitutional text and history, why is Congress prohibited from concluding that citizens who have suffered an injury should be allowed to require violators of the law to pay appropriate penalties to the government? The history suggests a far broader

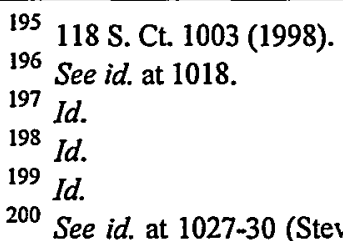
from its previous treatment of cases without redressability). 
understanding of legislative power. ${ }^{201}$ Nonetheless, Steel Co. is consistent with the thrust of the Court's recent redressability holdings. It thus suggests that a plaintiff seeking information must show that if the suit is successful, the plaintiff will receive something for its trouble. If the plaintiff would receive the information, there is no problem. There is also probably no problem if the plaintiff would receive compensation or a bounty. If, however, the plaintiff stands to gain nothing else, standing will be denied.

The outcome in Steel Co. was presaged by an intriguing court of appeals case raising a similar problem of informational standing in a quite different setting. In Common Cause v. FEC, the court of appeals rejected a claim of standing on behalf of the plaintiff, a well-known organization interested in campaign finance issues. ${ }^{202}$ Common Cause alleged that in the 1988 Senate election in Montana, the Montana Republican Party and the National Republican Senatorial Committee had violated federal campaign election law by making excessive contributions and expenditures and by failing to accurately report these contributions. The latter claim suggested an interest in obtaining information. In denying standing, the court said that the mere fact of deprivation of knowledge as to whether there had been a violation of the law could not, by itself, create standing; this, according to the court, would be equivalent "to recognizing a justiciable interest in the enforcement of the law."203 But if Common Cause was "asserting an interest in knowing how much money a candidate spent in an election," then it would have standing to protect that "legally cognizable injury in fact."204 (This point is very much in line with the conclusion in Akins.)

Here, however, Common Cause sought investigation and the imposition of monetary penalties, rather than disclosure itself. Thus, a central problem for standing was that the monetary penalties would not benefit Common Cause at all. Concurring, Judge Sentelle stressed this point and its connection to the problem of redressability. In his view, the imposition of monetary penalties would only speculatively produce future compliance with the law-penalties themselves would not redress any injury. ${ }^{205}$ But Judge Sen-

201 See Sunstein, supra note 137, at 173-74 (discussing the suggestion of a historical survey that "the public action-an action brought by a private person primarily to vindicate the public enforcement of public obligations-has long been a feature of our English and American law" (citation and internal quotations omitted)).

202108 F.3d 413 (D.C. Cir. 1997).

203 Id. at 418.

${ }^{204} \mathrm{Id}$.

${ }^{205}$ See id. at 419 (Sentelle, J., concurring) ("If the injury alleged were the cognizable deprivation of information upheld in Akins, administrative discipline of the alleged wrongdoers would not remedy that injury.") 
telle also acknowledged that the "redressability requirement can be satisfied by requesting that the wrongfully withheld information be disclosed."206

We may thus draw several conclusions. There is no problem with redressability if the plaintiff seeks to obtain information, compensation for information withheld, or (though this is less clear) a bounty for information withheld. But a problem of redressability will arise if Congress grants citizens standing to seek declaratory judgments, attorney's fees, or penalties to be paid to the Treasury for information withheld. If Congress wants to allow standing in cases like Steel Co. and Common Cause, then it should amend the relevant statutes to provide a financial benefit not only to the Treasury, but also to the plaintiffs, in the form, perhaps, of fixed or scheduled compensation for information withheld, and also (or instead) a small bounty for the trouble of bringing suit. This would be easy to do. Although the question is not entirely settled, a statute of this kind probably would, ${ }^{207}$ and certainly should, ${ }^{208}$ be upheld.

\section{Generalized Grievances Within the Zone?}

The Akins Court dealt with a statute that, in its view, unambiguously granted standing to the plaintiffs. But many informational standing cases involve the APA, and therefore involve ambiguity about the issue of standing. The APA grants standing to any "person suffering legal wrong because of agency action, or adversely affected or aggrieved by agency action within the meaning of a relevant statute."209 What does this provision mean in the context of a request for information? Here there is a question of statutory interpretation; and recall that the Akins Court suggested that there remains a prudential barrier to "generalized grievance[s]."210 Thus there is a further question about how prudential barriers are to be understood when people seek to obtain information from government or private persons.

The best way to approach this complicated problem is by examining a series of cases in the D.C. Circuit Court of Appeals. The basic suggestion in these cases is that if the governing statute is ambiguous, then standing will be denied in informational cases where the plaintiff is one of a very large group of people. The denial is based on prudential rather than Article III grounds, and hence Congress can, in these cases, grant standing if it

${ }^{206}$ Id. at 420 (Sentelle, J., concurring).

207 See supra note 194 (providing statutory and case support for such a bounty system).

208 See Sunstein, supra note 137, at 173-79, 232 (discussing the historical support for, and the substantial merits of, a bounty system).

209 5 U.S.C. $\$ 702$ (1994).

210 Federal Election Comm'n v. Akins, 118 S. Ct. 1777, 1785 (1998). 
chooses. The question is whether, and to what extent, this line of argument makes sense in general or after Akins in particular. To answer this question it is necessary to investigate the cases in some detail.

The initial case, and the origin of the doctrinal developments, did not principally involve informational standing. In Haitian Refugee Center $v$. Gracey, the plaintiff organization claimed that it had an interest in counseling and representing Haitians who had been interdicted from entering the United States. $^{211}$ The court concluded that this interest was not within the zone of rights created by the relevant laws, and therefore, that the plaintiff lacked standing to protect the relevant rights. ${ }^{212}$ This conclusion applied to the plaintiff's particular claim that it should have been allowed to receive pertinent information from the interdicted Haitians:

If any person or organization interested in promoting knowledge, enjoyment, and protection of the rights created by a statute or by a constitutional provision has an interest that falls within the zone protected or regulated by the statute or constitutional provision, then the zone-of-interest test is not a test because it excludes nothing. ${ }^{213}$

The court insisted in particular that the zone of interests test should be read in the light of the ban on standing based on a "generalized grievance"; ${ }^{214}$ if a plaintiff claiming to be within the zone was a member of a large class, then standing should be denied. This was of course not a "pure" information case, since it did not involve a statute that required disclosure of information. But it has turned out to be quite important in such cases.

In the first case using this kind of reasoning to deny informational standing, the D.C. Circuit Court of Appeals refused to allow the Hazardous Waste Treatment Council to assert an unambiguous informational injury. ${ }^{215}$ The Council sought to sue on the ground that regulated third parties were exempted from certain statutory reporting requirements under a hazardous waste statute. ${ }^{216}$ The Council claimed that the exemption would make it harder for the Council to advance its "educational and promotional activities." 17 In denying standing, the court did not deny that there was an injury in fact. Instead it said that the Council's goals did not fall within the rele-

211809 F.2d 794 (D.C. Cir. 1987).

212 See id. at 813-16 (examining the zone of interests that is created by the relevant laws).

213 Id. at 813.

214 Id. (citing Schlesinger v. Reservists Comm. to Stop the War, 418 U.S. 208 (1974), and United States v. Richardson, 418 U.S. 166 (1974)).

215 See Hazardous Waste Treatment Council v. EPA, 861 F.2d 277, 287 (D.C. Cir. 1988) (holding that a plaintiff cannot attain standing for a generalized grievance simply by forming an organization that has as its goal furtherance of the interest at the heart of the grievance).

${ }^{216}$ See id. (summarizing the plaintiff's argument).

217 Id. at 286-87. 
vant statute's zone of interests, beyond a "general coincidence of goals."218 In so concluding, the court implied that it would read the prudential barrier in light of the additional prudential barrier that operated against generalized grievances. ${ }^{219}$ Thus the court suggested that the two prudential barriers would have a kind of synergy, preventing members of large classes from claiming information unless there was a clear indication that Congress intended them to be able to do so.

This line of thinking was extended in Animal Legal Defense Fund $v$. Espy. ${ }^{220}$ In that case, the Animal Legal Defense Fund and the Humane Society of the United States challenged the government's relatively narrow definition of "animal" for purposes of the Animal Welfare Act. ${ }^{221}$ More specifically, they complained that "the exclusion of birds, rats, and mice from the definition of 'animal' [would] hamper[] their attempts to gather and disseminate information on laboratory conditions for those animals."222 A broader definition would require laboratories to provide more information about their treatment of animals to the government, which would mean that such information would be included in an annual report to Congress. The relevant organizations contended that they would use this report in "public education and rulemaking proceedings., 223 In addition, the narrow definition of "animal" would make it harder for the organizations to educate the laboratories about "the humane treatments of birds, rats, and mice."224 The Animal Legal Defense Fund thus urged that it had standing to ensure that the information was disclosed, especially because the information would be central to its activities.

The court concluded that "informational injury, without more, does not fall within the zone of interests of the statute under which suit is brought." 225 The key point was that the Animal Legal Defense Fund was not attempting to promote its members' own legal rights, but "simply to educate all those who desire to promote the statute's substantive pur-

218 Id. at 287.

219 See id. (arguing that if any organization could secure standing by showing a general coincidence of goals with a statute, anyone could secure standing to challenge any action taken by the agency implementing that statute).

22023 F.3d 496 (D.C. Cir. 1994); cf. Animal Legal Defense Fund, Inc. v. Glickman, 154 F.3d 426 (D.C. Cir. 1998) (finding standing for someone claiming an aesthetic interest in observing animals).

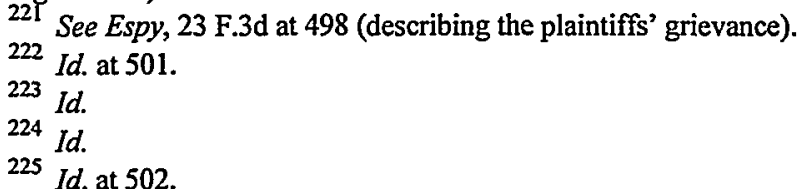


poses. ${ }^{, 226}$ To have informational standing under the zone of interests test, an organization must show far more than a "general corporate purpose to promote the interests to which the statute is addressed .... [I]t must show a congressional intent to benefit the organization or some indication that the organization is 'a peculiarly suitable challenger of administrative neglect.",227 Here, an unusual provision of the statute itself prohibited any such showing. The Animal Welfare Act creates an oversight committee consisting of private citizens designed to ensure compliance with the Act. ${ }^{228}$ In the court's view, "on the face of the Act the organizations are not the intended representatives of the public interest in animal welfare.",229

This holding is quite insecure after Akins; it should be contrasted with an important case in which organizations were held to have fulfilled the prudential requirements for informational standing. In Action Alliance of Senior Citizens v. Heckler, ${ }^{230}$ the court permitted a senior citizens' group to challenge regulations that restricted the flow of reports from third parties involving compliance with the Age Discrimination Act. The Action Alliance contended that these regulations would interfere with its basic mission. The court agreed, noting that the regulations would make it harder for the plaintiff organization to help elderly people now and to protect their legal interests in the future. ${ }^{231}$ In the court's view, this injury was well within the statute's zone of interests. The distinction between Action Alliance of Senior Citizens and Espy is thin. The best argument would stress the existence of a special private institution designed to ensure compliance with the Animal Welfare Act, but it is far from clear that this is a convincing distinction. ${ }^{232}$

To what extent must an organization seeking information connect its interest to the substantive purposes of the statute? This question was not

226 Id.

227 Id. (quoting Hazardous Waste Treatment Council v. EPA, 861 F.2d 277, 283 (D.C. Cir. 1988)).

${ }^{228}$ See 7 U.S.C. $\$ 2143$ (1994) (discussing the "standards and certification process for humane handling, care, treatment, and transportation of animals").

229 Espy, 23 F.3d at 503.

230789 F.2d 931 (D.C. Cir. 1986), vacated on other grounds, 494 U.S. 1001 (1990).

${ }^{231}$ See id. at 937-38 (identifying added expense and difficulty as the likely results of the restrictions on information).

${ }^{232}$ See infra text following note 244 (arguing that Congress's creation of a citizen review board in conjunction with the Animal Welfare Act does not adequately explain the preclusion of suit by the Animal Legal Defense Fund); see also Animal Legal Defense Fund, Inc. v. Glickman, 154 F.3d 426, 445 (D.C. Cir. 1998) (noting that the Animal Welfare Act did not establish private citizen committees to oversee animal exhibitions, but "anticipated the continued monitoring of concerned animal lovers to ensure that the purposes of the Act were honored"). 
pressed in the cases just discussed, all of which involved a close connection between the plaintiff's interests and the statute's basic concerns. In the leading case, Competitive Enterprise Institute v. National Highway Traffic Safety Administration, ${ }^{233}$ two organizations, the Competitive Enterprise Institute and Consumer Alert, brought suit to challenge the National Highway Traffic Safety Administration's ("NHTSA") decisions that lowered the minimum Corporate Average Fuel Economy ("CAFE") standards for passenger cars. Both organizations complained of NHTSA's failure to produce an EIS discussing the adverse safety effects of the CAFE standards. They argued that the absence of such a statement made it harder for them to obtain and disseminate information that was central to their organizational activities. In the abstract, their complaint had a high degree of plausibility insofar as fuel economy standards may have adverse safety effects-a point that, it is reasonable to think, deserves public attention when an agency is deciding how much to require in the way of fuel economy. ${ }^{234}$

The court held that an informational injury would be a legitimate basis for federal jurisdiction when the information is "essential to the injured organization's activities" and when "the lack of the information will render those activities infeasible." 235 To meet this standard, the organization "must assert a plausible link between the agency's action, the informational injury, and the organization's activities."236 The court, however, held that the plaintiff organizations did not have standing under this test to contest the agency's failure to provide an EIS. This was because there was no showing of "how the lack of that assessment from NHTSA ha[d] significantly harmed their ability to educate and inform the public about highway safety."237 The court acknowledged that, under previous cases, ${ }^{238}$ NEPA had been held to have created a right to information about the environmental effects of government action, and that a denial of that information "consti-

233901 F.2d 107 (D.C. Cir. 1990).

234 See John D. Graham, Saving Gasoline and Lives, in RISK VERSUS RISK: TRADEOFFS IN PROTECTING HEALTH AND THE ENVIRONMENT 87, 98-102 (John D. Graham \& Jonathan Baert Wiener eds., 1995) (discussing the important role of the Insurance Institute for Highway Safety in bringing the safety risks associated with stricter CAFE standards into the public policy debate).

\footnotetext{
${ }^{235}$ Competitive Enter. Inst., 901 F.2d at 122.

236 Id.

$237 I d$. at 123.

238 See National Wildlife Fed'n v. Hodel, 839 F.2d 694, 712 (D.C. Cir. 1988) (finding that the "elimination of the opportunity to see and use an EIS prepared under federal law does constitute a constitutionally sufficient injury on which to ground standing"), rev'd on other grounds sub nom. National Wildlife Fed'n v. Lujan, 928 F.2d 453 (D.C. Cir. 1991); Scientists' Inst. for Pub. Info. v. Atomic Energy Comm'n, 481 F.2d 1079, 1091 (D.C. Cir. 1973) (finding that NEPA requires EISs for technology development programs).
} 
tutes a constitutionally cognizable injury, without further inquiry into causation or redressability. $\$ 239$ In such cases, however, it would be necessary to show that the information sought involved a specifically environmental harm; "there is a critical difference between seeking an EIS for the purpose of disseminating information about potential environmental harm and seeking an EIS as a vehicle for obtaining or disseminating information on a nonenvironmental issue. ${ }^{9240}$ The court emphasized that the plaintiffs, who did not invoke environmental concerns, were not within NEPA's zone of interests, which involved strictly environmental consequences of government action. ${ }^{241}$

With respect to the application of prudential requirements to informational actions, the lower court rulings thus reflect considerable complexity. But three propositions seem to underlie the rulings, and we can organize the law in the following way. First: An organization may sue to obtain information when that information is important to protect its members' (noninformational) statutory legal rights, at least if the injury is not widely generalized. This premise is the basic point of Action Alliance of Senior Citizens. Second: When an organization seeks information and when its interests are very widely shared, the courts will deny standing on prudential grounds, apparently even if the information is important to the organization's mission. Third: Under NEPA (designed to safeguard environmental goals) and other statutes designed to protect interests that are not purely informational, an organization can bring suit to require an EIS or otherwise to obtain information essential to its activities if the reason for bringing suit is to protect interests that are specifically environmental or otherwise in line with the statute's substantive goals. This third proposition, however, is subject to qualification from the second. With suitable amendments, these propositions appear to apply to individuals as well.

Akins does not say a great deal either to undermine or to support these conclusions-Akins suggests only (what the lower court cases do not deny) that Congress can grant purely informational standing if it chooses. If the lower court cases remain good law, then most of the doctrinal work in challenging attempts to bring suit for information will be prudential. Courts will ask (1) whether the plaintiff falls within the statute's zone of interests; (2) whether the plaintiff is part of a very large class; and (3) whether the information is relevant to the organization's activities in protecting independent legal interests (for example, the interest in environmental quality or freedom

${ }^{239}$ Competitive Enter. Inst., 901 F.2d at 123.

$240 \mathrm{Id}$.

241 See id. (stressing that standing under NEPA has only been granted when the plaintiffs' interests relate to environmental interests protected by NEPA). 
from age discrimination). It is relevant in this regard whether the zone of interests test is generally meant to be strict or lenient; the Court's most recent pronouncement in National Credit Union Administration v. First $\mathrm{Na}$ tional Bank \& Trust Co., ${ }^{242}$ suggests great leniency, in line with the basic thrust of other Supreme Court decisions. ${ }^{243}$

For those who believe, as Akins itself suggests, that the key standing issue is whether Congress has authorized the suit, the problem in all of these cases is simple to pose: Is this the kind of plaintiff whose interests are safeguarded by the legal provision at issue? If this is the proper question, then perhaps standing should have been allowed in all of the cases above, with the exception of Competitive Enterprise Institute, in which the plaintiffs' complaint lay far outside the domain of statutory concerns. Thus, there is reason to think that some or many of the lower court cases should not survive Akins.

Consider, for example, the Animal Welfare Act. If an ordinary citizen concerned with animal welfare sought to require the regulations at issue in Espy, a response might be that the ordinary citizen should not be allowed to sue unless she can show a distinctive personal or professional interest in the protection of animals or in the use of the relevant information; otherwise, the case would seem to involve an interest in law enforcement for its own sake. Espy itself, however, was quite different. The Animal Legal Defense Fund had a special and particularized interest in the relevant information and in disseminating it, as a way of protecting the legal rights protected by the Animal Welfare Act. Thus, the Animal Legal Defense Fund was well within the statute's zone of interests and had no widely generalized injury.

The best justification for the lower court's conclusion in Espy is that Congress implicitly precluded the suit by creating a citizen review board. This would suggest that the outcome was a narrow one, based on the distinctive structure of the Animal Welfare Act. Perhaps one could argue not

242118 S. Ct. 927, 938 (1998) (finding that the "interest [of competing financial institutions] in limiting the markets that [federal] credit unions can serve" is within the statute's zone of interests); see also Animal Legal Defense Fund, Inc. v. Glickman, 154 F.3d 426, 444 (D.C. Cir. 1998) (stating that "the zone of interests test is generous and relatively undemanding").

${ }^{243}$ See Clarke v. Securities Indus. Ass'n, 479 U.S. 388, 396 (1987) (finding that the trade association has standing because its interests are "arguably within the zone of interests to be protected"); Association of Data Processing Serv. Orgs., Inc. v. Camp, 397 U.S. 150, 154 (1970) (noting that "the trend is toward enlargement of the class of people who may protest administrative action"). But see Air Courier Conf. v. American Postal Workers Union, 498 U.S. 517, 517-18 (1991) (arguing that the union's interests were outside the zone of interests because the monopoly statute's purpose was to give an economic advantage to the Postal Service and not to protect postal jobs, and, therefore, holding that postal workers have no standing to challenge the Service's decision to allow competition in international remailing services despite its statutory monopoly). 
that there was a prudential barrier to standing, but instead, that Congress implicitly had prohibited the suit. Such an argument is analogous to the reasoning of Block v. Community Nutrition Institute, in which the Court denied standing on similar grounds. ${ }^{244}$ If the creation of the review board did in fact represent a decision not to allow private supervision in the form of suits by people within the zone of interests, a denial of standing would be perfectly appropriate. As a matter of statutory interpretation, however, this argument is fragile. Why should we view the review board and the courtroom as competing rather than complementary? Since the plaintiffs had a distinctive organizational interest in the relevant information, standing should have been granted.

The analysis would be similar with respect to informational standing under NEPA. Note first that in the ordinary NEPA case, the plaintiff seeks not information but a delay in the completion of a project until an EIS is produced; hence, the plaintiff must show, as a matter of interpretation of NEPA, that he has a distinctive stake, usually environmental, in the action. ${ }^{245}$ For example, a citizen of Wyoming who complains about the failure to compile an EIS about a development in New York must show that the development would in some way affect his aesthetic, recreational, or material interests. This citizen should ordinarily be denied standing because no interest protected by NEPA supports his action. But a question remains. After Akins, might the citizen of Wyoming contend, not that he sought an EIS to protect his environmental interests in New York, but that he sought an EIS in order to receive information about important issues bearing on his duties and activities as a voter?

The best answer is that the citizen of Wyoming could not so contend. The mere fact that the relevant EIS would produce information of personal or professional interest is not enough-not, it must be added, as a matter of Article III, but as a reading of congressional instructions and concerns in

244467 U.S. 340,348 (1984) (holding that consumers may not obtain judicial review of milk market orders under the Agricultural Marketing Agreement Act because the Act does not contemplate such suits).

245 See Sierra Club v. Morton, 405 U.S. 727 (1972) (holding that the petitioner lacked standing because it failed to show "individualized harm to itself or its members"). According to this view, the holding in Sierra Club is largely an interpretation of NEPA. There is no injury in fact because NEPA created no legal interest! If this formulation seems odd, consider its similarity to the analysis in Akins. Akins had an injury in fact because he had a legal interest. Extending this analysis, Sierra Club is very similar to United States v. Richardson, 418 U.S. 166 (1974), in which the Court held that the taxpayer did not have standing because he failed to show an injury or immediate danger of legally cognizable injury. In both cases, standing was denied because the relevant provision of law did not create individual rights. 
enacting NEPA. ${ }^{246}$ It is here that the zone of interests test and the prudential barrier to generalized grievances meet-not as inferences from Article III or even the APA, but as a somewhat crude and indirect way of getting at the key question, which relates to the text and purposes of the statute pursuant to which the plaintiff initiates suit. Thus, the appropriate conclusion is that when a court denies standing to a plaintiff on the ground that its interest is both highly generalized and not within the zone of statutory interests, it is really saying that the underlying statute is best read not to allow suits by plaintiffs of that sort. As we have seen, this is the best defense of the "injury in fact" and "redressability" standards as well. And the best defense of the lower court cases denying standing on this rationale is that when the injury is highly generalized, there should be a presumption against standing on the ground that such injuries are best redressed politically. Congress can overcome that presumption if it chooses to do so.

\section{Illustrations}

With these basic conclusions, we can assess a series of stylized cases, drawing on the discussion thus far.

1A. A group of workers in a plant in Detroit brings suit against the plant for failing to disclose workplace risks. They seek full information about those risks, as is required (in their view) by the governing law. This is an easy case. Standing should be granted, even in the absence of an explicit statute authorizing standing. The plaintiffs have shown both injury (nondisclosure of information undoubtedly relevant to them) and redressability, and no problem exists under the prudential requirements.

1B. Cereal consumers bring suit against General Cereal for false and incomplete statements involving the nutritional content of food. They seek full disclosure and compensatory damages. Standing should be granted, even in the absence of an explicit statute. The case is slightly harder, but basically the same as case $1 \mathrm{~A}$. The strongest argument against standing is that the class of plaintiffs is very large and, hence, that the grievance is gen-

246 If Congress allowed anyone to bring suit to require compliance with NEPA-not because of any specifically environmental interests but because of a general interest in the information at stake-there would probably be no Article III issue. The strongest opposing argument would be that it is necessary to have a distinctly environmental interest in the backdrop, as in a case in which people located near a proposed causeway challenge the failure to prepare an EIS. As NEPA now stands, an environmental interest is indeed a requirement, and this view is best justified as a reading of NEPA itself, perhaps informed by prudential considerations. 
eralized, triggering a prudential barrier against standing. But since the plaintiffs are unambiguously within the relevant zone of interests, and since the difference from case $1 \mathrm{~A}$ is only one of degree, standing is available under Akins. The class of plaintiffs is not so extremely large as to trigger any prudential barriers.

1C. Television viewers bring suit against the American Broadcasting Company ("ABC"), complaining that $\mathrm{ABC}$ has failed to rate its programs adequately and thus failed to comply with the Telecommunications Act of 1996. As in example 1B, the strongest argument against standing is that the grievance is widely generalized and, hence, that standing should be denied on prudential grounds. If the plaintiffs consist of television viewers as such - which is to say the vast majority of Americans-standing should probably be denied for that reason. The case would be different if brought by parents of school age children, a more limited group whose members fall squarely within the zone of interests protected by the Telecommunications Act. The case would also be different if the plaintiff was an organization particularly interested in the content of television programming; in that case, it would closely resemble $1 \mathrm{~B}$, and standing should be granted.

2A. A group of citizens in New York and Connecticut complains to OSHA that firms in Illinois have not been required to disclose workplace risks. In the face of OSHA inaction, the citizens in New York and Connecticut bring suit, contending that the information would help them in their capacity as citizens; if they learn about workplace risks, then they will know more about how to vote and about what political activities would be most worthwhile. Standing should be denied. The plaintiffs do not fall within the zone of interests protected by the Occupational Safety and Health Act.

2B. Citizens for Safe Workplaces ("CSW"), a Washington, DC organization, brings suit against OSHA, contending that it has failed to require disclosure of workplace risks in Detroit. CSW has no members in Detroit, but its members include many people interested in promoting workplace safety and workers in various states. CSW seeks disclosure of the information on the ground that CSW could use that information in its various educational and political activities. This is a hard standing case. The best argument against CSW is that CSW does not include Detroit workers and therefore is not within the zone of interests protected by the statute, a conclusion that could be fortified by invoking the prudential barrier to generalized grievances. Because CSW would use the information in activities directly related to workplace safety, however, it stands out from the public at 
large, and CSW should be permitted to bring suit. This conclusion is consistent with the analysis of NEPA in Competitive Enterprise Institute. ${ }^{247}$

3. Citizens for a Nuclear-Free Environment, an environmental organization based in California, attacks the adequacy of an EIS produced in connection with a nuclear power plant to be built in Massachusetts. The organization contends that an adequate statement would be extremely helpful in its political and educational activities. This is also a hard standing case, and it would be reasonable to deny standing on the ground that the interest is highly generalized and that only those in Massachusetts, with environmental interests at stake, should be permitted to bring suit. Probably the better conclusion, however, is that informational standing should be granted on the theory that the plaintiffs are well within the zone of interests protected by NEPA; Competitive Enterprise Institute supports this conclusion. $^{248}$

4. Consumers in Los Angeles challenge a Los Angeles water supplier's failure to provide adequate information about its performance in connection with the Safe Water Drinking Amendments of $1996{ }^{249}$ They seek the relevant information, which they contend is relevant to their behavior as consumers of water in the local area. This is an easy standing case; it is akin to case $1 \mathrm{~A}$ above.

5A. A reporter for The Washington Post brings suit against the Department of Health and Human Services, complaining that his work has been hindered by the government's unlawful failure to require disclosure of certain practices under the Medicaid statute. The plaintiff contends that the relevant information would be extremely valuable in his professional activities. Standing should probably be denied on the ground that reporters are not within the zone of interests protected by the Medicaid statute.

5B. The Gray Panthers, a group dedicated to the welfare of elderly people, brings the same suit as in $5 \mathrm{~A}$, contending that it needs the informa-

247 See 901 F.2d 107, 122-24 (noting that, even under the more liberal standing requirements used in NEPA-related cases, a "right to specific information under NEPA has so far been recognized for standing purposes only when the information sought relates to environmental interests that NEPA was intended to protect").

248 See id. at 122 (stating that standing is granted to those who have suffered "[an] injury to an interest within the zone of interest protected by [NEPA]").

24942 U.S.C. $\S 300$ j-21 (1994 \& Supp. II 1996) (outlining additional requirements to Title XIV of the Public Health Service Act, regulating drinking water). 
tion in order to perform its various public interest activities and in order to promote the well-being of its members. Standing should be granted because the injury is not so highly generalized, and because the group contains members who are unambiguously within the zone of interests protected by the statute.

5C. A daughter of an elderly woman receiving Medicaid brings the same suit as in $5 \mathrm{~A}$, contending that she would like to see the relevant information in order to ensure that her mother is being treated in accordance with the law. This is a very hard case. On the one hand, the interests at stake are those of a beneficiary of the Medicaid program, and the child of a beneficiary has a distinct and not merely ideological interest in the problem. On the other hand, the beneficiary of the program is not the plaintiff (compare with 5B) and a large number of people might reasonably claim that they are interested, financially or otherwise, in the legality of the government's behavior under the Medicaid statute. Clearly, Congress could grant standing in this case if it chose to do so, but if there is no express grant, then standing should probably be denied on the ground that the case is somewhat closer to $5 \mathrm{~A}$ than to $5 \mathrm{~B}$.

\section{E. The Implications of Informational Standing for Noninformational Standing: A Brief Note}

How does all this bear on standing in general? Several important points are clear. So long as there is an injury, Congress can grant standing to plaintiffs even if their injuries are very widely shared. Whether there is an injury depends largely on what the law says. In addition, whether the case involves information or something else, there is no redressability problem even if an agency, having lost on the legal question at issue, might have discretion to do what it originally did on some other ground. Thus a majority of the Court has repudiated the plurality opinion in Lujan insofar as it concluded that there would be a serious problem with redressability. ${ }^{250}$

The most interesting questions involve Congress's authority to create novel legal interests and to give people the power to bring suit to protect those interests in court. Congress might, for example, give everyone an interest in information of a certain sort (as it did in both FOIA and FECA, and might do in other contexts as well); Akins plainly says that this is constitutional. If Congress can do that, perhaps it also has a great deal of room to

250 See Lujan v. Defenders of Wildlife, 504 U.S. 555, 568-71 (1992) (noting that the plaintiffs, in challenging a "generalized level of government action," failed to present a case for the redressability of their specific injuries in fact). 
create novel interests that do not involve information. Perhaps Congress could give all citizens a property interest in the continued existence of endangered species (making each of us beneficial owners of a particular sort), or in maintaining certain land in a pristine state, or in clean air in certain regions of the country, or in a certain kind of telecommunications market. After Akins, why is Congress forbidden from saying that all Americans have a property interest in clear skies above the Grand Canyon, a property interest that exists regardless of whether the citizens in question actually visit the Grand Canyon? 251 $^{25}$

A possible answer-not ruled out by current law-is that such a statute would be unconstitutional because those who do not visit the Grand Canyon lack an "injury in fact."252 The same might be said about the hypothesized cases involving endangered species, land, and telecommunications. But if Congress says that they have an injury in fact, why should courts disagree? Note that "existence value" is often treated as a kind of property interest for purposes of environmental valuation; ${ }^{253}$ it is now conventional in contingent valuation studies to consider the amount that people are willing to pay in order to maintain a certain state of affairs. This very practice treats the continued existence of that state of affairs as a kind of property interest. Why can't Congress do the same thing? In any case, a property interest often is no more, and no less, than a cause of action. If Congress attempts to create a cause of action in a certain state of affairs and grants that cause of action to all Americans, there appears to be no constitutional barrier, especially after the Akins Court's unambiguous holding that the obstacle to generalized grievances is merely prudential.

Justice Kennedy presaged this judgment with his cautionary notes in Lujan, quoted as the first epigraph to this Article: "Congress has the power to define injuries and articulate chains of causation that will give rise to a case or controversy where none existed before. ${ }^{254}$ Justice Kennedy joined the Lujan opinion only because in creating citizen standing under the En-

251 People are often willing to pay a good deal for the "existence" of certain environmental amenities, and that existence value often plays a role in contingent valuation studies. See DAVID W. PEARCE \& R. KERRY TURNER, ECONOMICS OF NATURAL RESOURCES AND THE ENVIRONMENT 137-40 (1990).

${ }^{252}$ Cf. Lujan, 504 U.S. at 560 ("[T] he plaintiff must have suffered an 'injury in fact' ... which is (a) concrete and particularized and (b) 'actual or imminent ...."' (citations omitted)); Sierra Club v. Morton, 405 U.S. 727, 735 (1972) (holding that the Sierra Club had failed to demonstrate how any of its members would be affected by the challenged development).

See supra note 251; see also Ohio v. United States Dep't of the Interior, 880 F.2d 432, 464 (D.C. Cir. 1989) (upholding contingent valuation that allows use of "existence value" and "option value").

254 Lujan, 504 U.S. at 580. 
dangered Species Act, Congress failed to "identify the injury it seeks to vindicate and relate the injury to the class of persons entitled to bring suit."255 FECA is quite different on this count. Congress clearly identified the relevant interest, which was unambiguously related to the grant of standing to citizens. Thus, Akins vindicates Justice Kennedy's point and his concern about the breadth of Lujan insofar as it shows that Congress may recognize an entirely new (and highly generalized) legal interest, one foreign to the common law, and give all citizens standing to vindicate that interest in court. After Akins, whether a deprivation of information counts as an injury (in fact!) depends on whether it is (alleged to be) against the law. And after Akins, it does not matter if that injury is shared by most or all citizens-at least to the extent that Congress says this does not matter.

If this is true with information, why is it not true with many other interests? Why, for example, is Congress not permitted to give standing to all drivers to challenge acts that increase the risk of accidents on highways; ${ }^{256}$ or to give standing to parents of children in schools undergoing desegregation plans to allow them to challenge the grant of tax deductions to segregated schools; ${ }^{257}$ or to give standing to automobile purchasers and environmental organizations to ensure that the EPA enforces statutory requirements for fuel economy standards? ${ }^{258}$ The best answer is that Congress is indeed permitted to do these things. ${ }^{259}$ To the extent that similar cases have come out unfavorably to plaintiffs, it is because the governing statutes, interpreted in the light of relevant prudential requirements, reflect no effort by Congress to do so. Akins would not have had standing if Congress had denied him standing. Because of the prudential barrier to generalized grievances, Akins would probably not have had standing if FECA had merely incorporated the APA's standing provision. Denials of standing in cases involving novel interests foreign to the existing legal culture are therefore best understood as interpretations of the underlying statute. Congress's challenge for the future-if it genuinely seeks to grant standing-is to think of imaginative

255 Id.

256 See International Bd. of Teamsters v. Peña, 17 F.3d 1478, 1483-87 (D.C. Cir. 1994) (holding that the union had standing to challenge the Memorandum of Understanding between the United States and Mexico regarding recognition of foreign commercial drivers' licenses).

257 See Allen v. Wright, 468 U.S. 737, 753 (1984) (holding that parents seeking relief for the IRS's failure to fulfill its obligation to deny tax exempt status on racially segregated schools failed to demonstrate a judicially cognizable injury).

258 See supra note 140 and accompanying text.

259 See Animal Legal Defense Fund, Inc. v. Glickman, 154 F.3d 426, 445 (D.C. Cir. 1998) (recognizing an aesthetic interest in observing animals). 
ways to create legal interests in the rights it intends to protect. ${ }^{260}$ With this point, we end where we began: an assertion of the primacy, for purposes of Article III, of legislative instructions.

\section{CONCLUSION}

In this Article, I have attempted to outline the range of statutes that attempt to use information as a regulatory tool; to understand their rationale, their potential value, and their potential pathologies; to see when citizens are, and should be, granted standing to obtain information; and to understand how all these points bear on the general law of standing. We have seen that American government frequently, and increasingly, avoids both market and command-and-control solutions by using information disclosure as a regulatory tool. Sometimes informational strategies attempt to improve the ordinary operations of markets by ensuring that workers and consumers are adequately informed. Initiatives involving tobacco products, the nutritional content of food and drink, and worker safety are primary examples. Sometimes information is required as part of moral suasion and in order to trigger political safeguards. EPCRA and FECA are the chief examples here.

Typically information, once provided to one or a few, is also provided to many or all; and very frequently information is required as a way of protecting against a widely shared injury. In the political context, the injury from nondisclosure may be suffered by a large number of citizens. After Akins, this is not an obstacle to standing, and properly so-assuming that Congress has concluded that it ought not be. Nothing in the Constitution forbids Congress from authorizing groups of citizens to bring suit to obtain information that they believe is relevant to their interests. Nor does anything in the Constitution forbid Congress from granting citizens a legal right to information and allowing them to vindicate that right in court. This holding - a crucial part of Akins-is a vindication of Justice Kennedy's highly suggestive concurring opinion in Lujan, allowing Congress to create injuries quite foreign to the common law.

Things are more complicated with respect to redressability. In Akins itself, the injury - a lack of information—would have been redressed by a fa-

${ }^{260}$ Examples are briefly given above involving endangered species and visibility. More particularly, Congress might say, for example, that Americans have a shared property interest in the continued existence of endangered species, an interest that is violated whenever the federal government acts unlawfully under the Endangered Species Act, 16 U.S.C. \$\$ 1531-34 (1994), and an interest that can be protected by citizen suits. A statute of this kind might be strengthened by reference to the role of "existence value" in ordinary cases of environmental valuation. I do not suggest that Congress should do this as a matter of policy; the answer to that question depends on context. 
vorable decree. The information itself need not have been linked to any independent interest. Nor was it important that the FEC might ultimately have exercised its discretion unfavorably to the plaintiffs. This conclusion offers an important lesson about the nature of procedural injuries: procedures are designed to structure decisions and to create incentives, not to command particular outcomes, and an injury to a procedural interest need not be tied to a nonspeculative outcome. It follows that courts should be careful and self-conscious about characterizing the injury of which the plaintiff complains. I suggest that Akins may be the first step toward a more explicit confrontation, on the Court's part, with that important question.

What about the prudential limitations? When Congress has not explicitly granted standing to those who seek information, it is important to know what the relevant law says. In many cases involving informational standing, there is no difficult question about whether the plaintiffs fall within the zone of interests protected by the statute. It is possible, however, to imagine cases in which those who seek information are attempting to vindicate interests, economic or ideological, that have little to do with the statute's substantive goals. In such cases, the prudential limits on standing are properly invoked and the plaintiffs should be held to be outside the zone of statutory interests. Furthermore, if the plaintiff is a member of a large group, or is hard to distinguish from other citizens generally, the argument for invoking prudential barriers is strengthened. We have examined a range of possible cases to see how this analysis might work. The simplest point is that if an injury is very widely shared, then there is reason to deny standing if the case is, with respect to the zone of interests test, otherwise in equipoise.

Beyond these doctrinal points, the Akins decision deserves a more general celebration. It is the first case in a long while to place the law of standing on a solid foundation-an understanding of the particular statutory and constitutional provisions that are said to give rise to a legally cognizable injury. But there is a more particular point, involving the relationship of information to regulatory law. In the same period in which the American economy increasingly has become based on the production and exchange of information, American government has increasingly attempted to control public and private conduct-not via command-and-control regulation, but by requiring disclosure of information. And in the same period in which informational regulation has become a hallmark of American government, informational standing has increasingly emerged as a central problem in administrative law. There is nothing constitutionally problematic about a congressional judgment that a deprivation of information counts as legally cognizable injury. The question is whether Congress has made that judgment. In the area of informational standing, as in the law of standing gener- 
ally, the relevant statutory law is the best place to start, rooting the doctrine in democratic rather than judicial judgments about the appropriate nature, and boundaries, of modern regulatory government. 
* $\quad * \quad * \quad * \quad * \quad *$ 